\title{
The Nature of Norms in Early Modern England: Anatomy, Cartography, King Lear
}

\author{
Valerie Traub, University of Michigan, Ann Arbor
}

\begin{abstract}
One reason why you won't find many eloquent quotations about the desire to be normal in Shakespeare, or the Bible, or other common sources of moral wisdom, is that people didn't sweat much over being normal until the spread of statistics in the nineteenth century.
\end{abstract}

Michael Warner, The Trouble with Normal ${ }^{2}$

At the beginning of the play we are watching an old man and his awkward family. At the end all we can see is stricken Humanity holding murdered Nature in its arms.

John Danby, The Doctrine of Nature in King Lear ${ }^{3}$

ONE OF THE MOST ARRESTING allusions to nature in King Lear is when the distraught king, emotionally battered by his daughters and the weather, directs in Act 3: "Then let them anatomize Regan; see what breeds about her heart. Is there any cause in nature to make these hard-hearts?"4 Until recently, Lear's vengeful query about the nature of Regan's cruel, impervious heart has been interpreted as more a cogent metaphysical metaphor than a serious epistemological inquiry. ${ }^{5}$ Yet, as critics have begun to argue, given the emergent practice of anatomical dissection in the early modern period, it is clearly both. ${ }^{6}$ In this, Shakespeare follows the lead of Renaissance anatomy, which collapses distinctions between metaphysics and epistemology, simultaneously posing questions of ontology (what is the nature of corporeal being?) and modes of knowing (through what procedures can we know it?). With his direct injunction to "anatomize Regan," Lear expresses the hope, not only that bodies and behaviors ultimately will be rendered intelligible by reference to a nature ordained by the gods, but that previously unknown truths of human nature might be revealed by the empirical procedures of human dissection being institutionalized in anatomy theaters across Western Europe.

Lear's reference to anatomizing the heart is a common enough literary trope, present, for instance, in Ford's 'Tis Pity She's a Whore, Tourneur's The Atheist's Tragedy, and Jonson's Volpone, and its thematization has been aptly analyzed by critics who have focused on the perceived brutality of anatomy in the early modern period, the striking architectural 
and spectatorial affinities between London playhouses and continental and English anatomy theaters, ${ }^{7}$ the subjection of the bodily interior to anatomy's scopic, penetrative, reifying gaze ${ }^{8}$ and the psychic and cultural anxieties elicited by what Michael Neill describes as "the maddening opacity of the human body." Within this criticism, King Lear holds theatrical pride of place for its anatomy of the world. Anatomy sums up both theme and plot in Shakespeare's play, wherein fragmentation, dismemberment, curses that vivisect the body, and even the gouging of Gloucester's eyes are utilized to visceral tragic effect. ${ }^{10}$ In this critical tradition on Lear and Renaissance literature more generally, scholars have emphasized the material and ideological violence of what Jonathan Sawday calls the Renaissance "culture of dissection," anatomy is conceived primarily as a destructive act — however much it also might, as in Devon Hodge's Fictions of Anatomy, serve as a powerful mode of revelation. ${ }^{12}$ Much of this scholarship has been directed toward answering the question: how does Renaissance literature and King Lear, in particular, weigh in on the epistemological claims and procedures of anatomy's "modern" science of the body? ${ }^{13}$

The other early modern science often credited with imparting to Lear much of its metaphorically allusive and culturally referential power is that of cartography. Beginning with the command in the folio version, "Give me the map there" (1.1.35) —or, in the first quarto, the laconic, "The map there" - the play's dependence on a "cartographic consciousness" has been analyzed as part of a wider exploration of how a geographical imagination and map-making underwrote early modern social relations, including the practice of historiography, the politics of land ownership, and the emergence of national identity $;{ }^{14}$ how geographic space, including landscape and nationscape, was textualized and performed $;^{15}$ the inherent theatricality of early modern cartography and, conversely, the effects of "mapmindedness" on Renaissance drama; ${ }^{16}$ and the use of maps as theatrical props-notably, in King Lear. ${ }^{17}$ Lear in fact has served as ground zero for literary critics interested in cartography, in no small part because, as John Gillies notes, Lear's map is "the most complex instance of map usage in Shakespeare"; it thus "can be taken as an exemplary instance for testing the nature of dramatic mediation of cartographic values." ${ }^{18}$ Gillies's query about cartography, repeated in other critical treatments of the play, echoes critics' prevailing concern with anatomy: "does the drama serve as a conduit of [cartographic] values, or does it play a more active and critical role, inflecting, qualifying, subverting, or challenging them?"19

As intriguing as this question is, it, along with the corollary question regarding the relations between anatomy and literature, implies that early 
modern literature exists in some realm other than that in which scientific discourse orders itself. Whether drama is a passive "conduit" or an active vehicle of meaning, it is, from this perspective, fundamentally separate from science, which appears to exist in a discursive, material, and epistemological domain of its own. Even as critics challenge the "history of ideas" paradigm whereby science serves as background for the literary imagination or literature reflects scientific ideas, ${ }^{20}$ even as they point to the numerous tropological schemes, questions, and values shared by science and literature, and even as they acknowledge that anatomy is more than an organizing metaphor and maps more than a crucial stage property, many analyses reproduce the assumption that the "literary" is somehow above or beyond the imperatives of science.

One purpose of this essay is to explore the proposition that, in the pre-disciplinary organization of knowledge of the late sixteenth and early seventeenth centuries, when separate fields of expertise had yet to be firmly demarcated, literary texts might be profitably construed as something other than (passive or active) agents vis-à-vis scientific discourses - whether inflecting, qualifying, subverting, or challenging science or, in turn, being inflected, qualified, subverted, or challenged by it. I propose that the texts we now deem "literary" comprise a mode of discourse that, while structured through distinct rhetorical forms, nonetheless exists within, partakes of, and contributes to the same epistemological domain in which scientific values, procedures, and logics were being developed. ${ }^{21}$ Even as literature and science produce different kinds of cultural and empirical knowledge, their common storehouse of representational strategies suggests that, at least in certain cases, the modes of knowing that they inaugurate may have been intimately related. In this respect, literary texts offer, not merely a privileged and evaluative comment on the pretensions of scientific thinking, but a unique rhetorical vantage from which one can examine the formal, syntactical maneuvers by which scientific discourses functioned and gained efficacy. The tropological, thematic, and structural complexity of literary texts-including their densely interwoven figurative language; self-reflexive, compound, antiphonal plots; and shifting points of view-provide multiple points of access to a broad array of representational strategies: from the metaphoric, metonymic, and mimetic to the structural, epistemological, and nonrepresentational. ${ }^{22}$ Precisely because of their rich hermeneutic complexity, literary texts enable us to ascertain with special clarity the formal logics and strategies they share with scientific texts.

Through its appropriation of anatomical and cartographic tropes and values, King Lear invites us to track such logics and strategies, even 
when it judges the content of scientific discourses to be lacking in some fundamental way. What primarily concerns me, then, is not the mimetic question of how Renaissance literature represents or assesses these new sciences, but rather: what access does King Lear provide regarding the role played by anatomy and cartography in contributing to novel structures of thought? Shifting the ground of analysis away from the operations of metaphor and mimesis and toward the epistemological effects of the interaction between literary and scientific texts, my analysis opens up onto the ramifications of the conceptual logics developed by anatomy and cartography and utilized by King Lear. What follows, then, is less a reading of the play's anatomical and cartographic consciousness than the excavation of a "style of reasoning" that King Lear shares with these two scientific endeavors. ${ }^{23}$

Shakespeare's play, I argue, participates in cultural logics that developed out of the material and conceptual interaction of anatomical illustrations of the human body and representations of human figures on maps. These logics were far more pervasive and socially productive than the limited practical applicability of medicine and geography. In proposing that the implications of an anatomico-cartographic logic in Lear extend well beyond the celebration or critique of maps or anatomies, my aim is to enact a form of historical epistemology, ${ }^{24}$ the purpose of which is to chart a genealogy of some of our culture's key concepts-in particular, the relation between the medieval concept of nature and the modern concept of norms. My genealogy traverses some of the conceptual distance between the radical historicizing to which the concept of "the normal" has been subject (in fields as diverse as literary criticism, the history of science, disability studies, and, as my epigraph from Michael Warner illustrates, queer theory) and the tight link between "Humanity" and "Nature" in John Danby's reading of Lear-whose universalism, despite the impact of twenty years of historicist readings, still informs our aesthetic appreciation of Shakespeare's plays. By bringing "the normal" into historical relation with "the natural," I aim to elucidate both what is distinctive and continuous in the styles of reasoning they represent.

To illuminate the various conceptual strands which comprise those styles of reasoning, I begin by noting that early modern anatomy and cartography are often associated with one another, indeed conflated, by virtue of the discourse of discovery that subtends them both - a point alluded to by Michael Neill when he characterizes anatomy as "a discipline which offered to lay bare the hidden truths of the human microcosm in very much the way that navigators and geographers had uncovered the secrets of the macrocosm." ${ }^{25}$ This acknowledgement of a shared discourse 
of discovery, however, often functions as an analytical blindspot: as if under the silent sway of Neill's analogy, critics of King Lear routinely have employed cartographic and anatomical metaphors interchangeably - most often to convey a form of violent investigation wrought upon an ever more fragmented body and body politic - even when neither anatomy nor cartography is their ostensible subject. Hodges, for instance, argues that in the "ritualized act of division [of the kingdom] meant to insure the survival of the body politic," Lear "uses the fragmenting methods of an anatomist." Philip Armstrong twice refers to "Lear's imperious dissection of the map and, by extension, the kingdom itself." And Gillies refers to Shakespearean drama's "cartographised anatomy," but never explains why this "nation-scape" functions as an anatomy. ${ }^{26}$

Such critics neither scrutinize the historical relations between anatomy and cartography, nor theorize their propinquity, nor explain what authorizes the substitution of one scientific discourse for the other. ${ }^{27}$ Taking seriously these intimations of a conjunction between anatomical and cartographic tropes as comprising both theme and structure in Shakespeare's play, I draw out what is implicit in these casual critical analogies, exploring underneath them to illuminate the epistemology that links them historically. The conflation I analyze operates at several levels: within the dramatic text, within the interpretative hermeneutics brought to bear on it, and within the interaction of scientific discourses themselves. Drawing these together I ask: What is the relation between "the scene of cartography in King Lear" to invoke Gillies, and its "fictions of anatomy" á la Hodges? What does it mean, materially, figuratively, and epistemologically, that anatomy so readily connotes cartography, and vice versa? What is the historical import of this substitution of one scientific discourse for another? Can King Lear give us any analytical purchase on the meaning of this tropological slide? And if so, what insight might we thereby achieve regarding Lear's repeated invocation of nature, and its relation to the modern concept of norms?

$$
* * *
$$

If anatomy and cartography function as powerful analogues for one another in interpretations of King Lear, it is in part because the play itself cannily merges its anatomic and cartographic tropes, themes, and structures. From the first mention of the map of Lear's kingdom, the play relentlessly enacts the fragmentation of that body politic as the cartographic corollary to the anatomical dissection of individual bodies. 
Contemporary theatrical and cinematic productions sometimes capitalize on this thematic correlation by employing performance strategies across the course of the action to call attention to an increasingly torn and tattered map. The tragedy that ensues is both abstractly spatialized as the partitioning of the kingdom (abstract because no kingdom could be fully represented on the stage) and corporeally materialized by images of violence and dissection visited on particular bodies. ${ }^{28}$

The doubled impact of anatomical and cartographic fragmentation haunts Lear in the "extremity" of his anguish under the tempestuous "skies" (3.4.92). Forced by his daughters' refusal of hospitality to flee to a "topographical dead zone" where he confronts heaven's apparent indifference, ${ }^{29}$ Lear encounters Edgar as the Bedlam beggar, Poor Tom. It is relevant that their encounter occurs as the king attempts to traverse the unmapped, indefinite, and, as A. C. Bradley noted long ago, confused topography of the play's imagined Britain. ${ }^{30}$ It is here, on uncharted territory, that Edgar elicits from Lear a response that verges on natural philosophy: his description of Poor Tom as "unaccommodated man," that "poor, bare, forked animal," "the thing itself" (3.4.95-6). ${ }^{31}$ And no wonder. Emaciated, "unaccommodated" by clothing, shelter, or kin, and pierced by self-inflected wounds, Poor Tom performs a dramatic rendition of the visual conventions that governed the graphic representation of anatomical specimens, from skeletons to partially dissected corpses. ${ }^{32} \mathrm{Vi}$ sually, Poor Tom's barely clothed, hyperkinetic, chattering figure recalls those animated, often madcap cadavers that, from the medieval period through the seventeenth century, cavort across the pages of anatomical textbooks (See Figures 1 and 2). Like them, he serves as an edifying figure for the increasingly mad, but increasingly interrogative king, eliciting from Lear an epistemological and pedagogical performance worthy of the anatomist's demonstration as he peels back successive layers of skin, muscle, organs, and veins (See Figure 3): "Is man no more than this? Consider him well" (3.4.93).

The significance of Lear's anatomical encounter with Edgar has underpinned countless critical treatments of the play. Whether celebrated as a dramatic tour de force of humanist empathy (the fallen king expressing sympathy for the beggar's desperate plight) or exposed as an ideological mystification of monarchical power (the inequity of poverty is not remediated by Lear's empathy), ${ }^{33}$ critics generally agree that this scene enacts Shakespeare's appeal to a paradigmatic universal: to abstract Man, to common humanity, to human kind, to human nature. ${ }^{34}$ In focusing our gaze on Poor Tom's material body and asking us to extrapolate from it to a general human condition, the play invites a metaphysical 


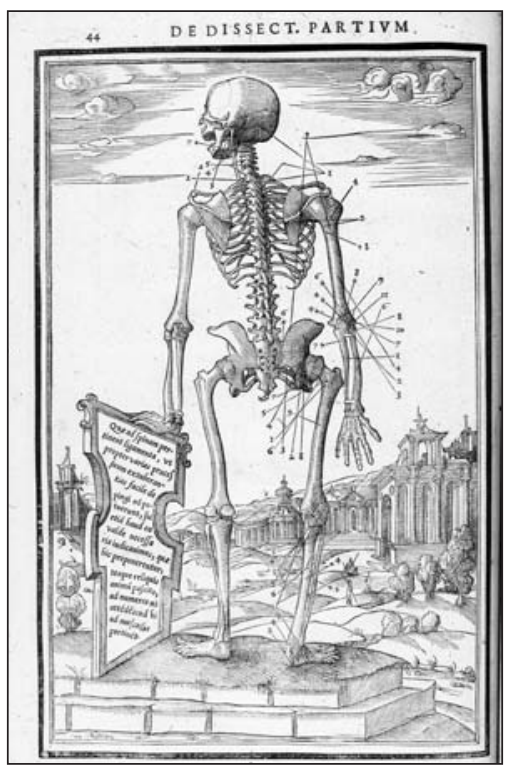

Figure I. Charles Estienne, "De Dissect. Partivm," La Dissection des Parties du Corps Humain (I 545). Credit: Rare Book and Manuscript Library, University of Pennsylvania.

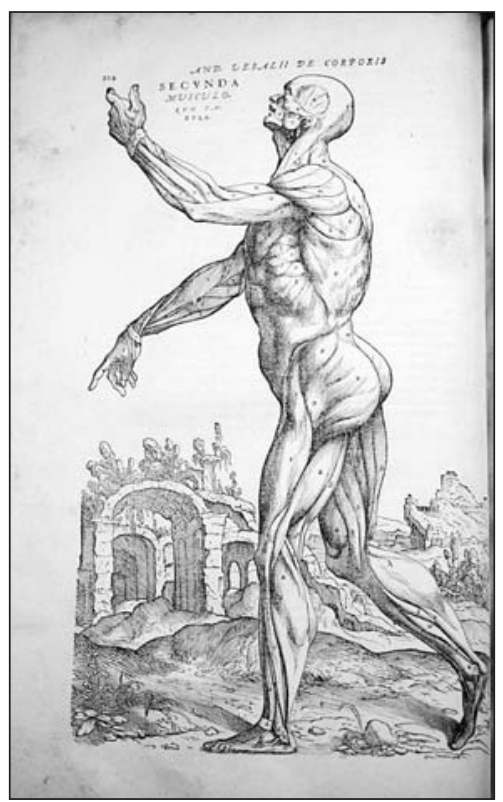

Figure 2. Andreas Vesalius, "Secunda Musculo," De Humani Corporis Fabrica (I 555). Credit: Historical Collection, Eskind Biomedical Library, Vanderbilt University Medical Center. 


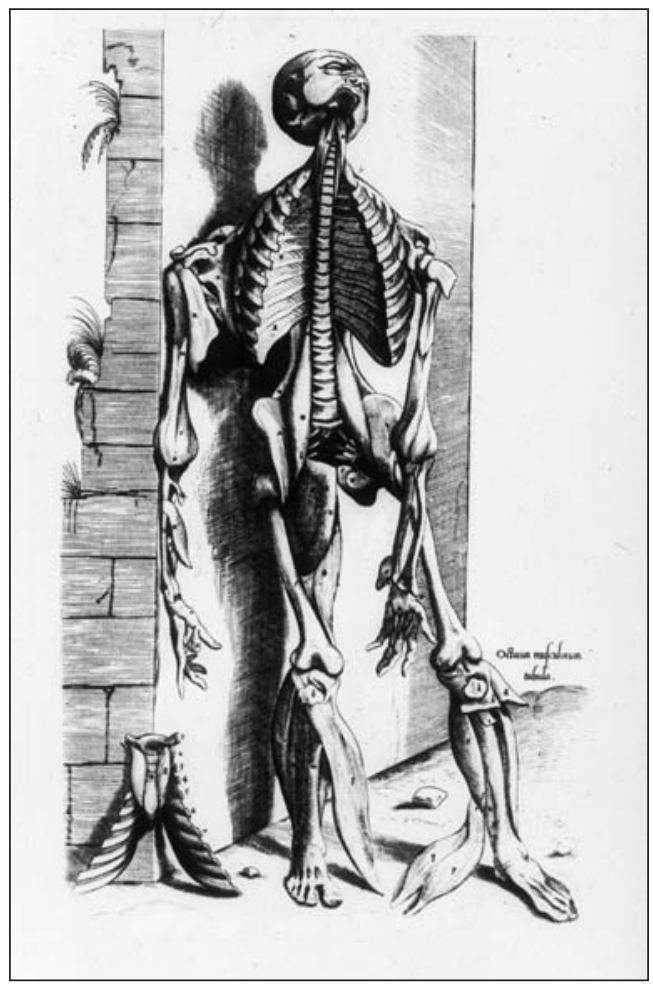

Figure 3. Thomas Geminus, Compendiosa totius anatomie delineatio (I545). Credit: Wellcome Library, London.

and epistemological appraisal, the aim of which, like that of anatomy, is to constitute a universal corporeal standard. Indeed, once we have noted the salience of anatomical pedagogy to this scene, we may discern Poor Tom's resemblance to that fascinating figure of early modern anatomical illustration, the self-demonstrating corpse (See Figure 4).

It is soon after encountering this edifying figure of dissection that Lear expresses his desire to "let them anatomize Regan; see what breeds about her heart." Lear's grim materialism here approaches the skeptical natural philosophy that other scholars, working within the tradition of intellectual history, have argued is the purview of the play's villains. ${ }^{35}$ But even as Lear clings to the hope of ascertaining "some stark but finally irreducible truth," he never discovers a "localized material cause" of Regan's hard heart; ${ }^{36}$ such certainty, whether ontological or empirical, seems beyond the scope of human inquiry. Indeed, Lear is as hapless an anatomist as he was cartographer; despite his temporary assumption of the anato- 


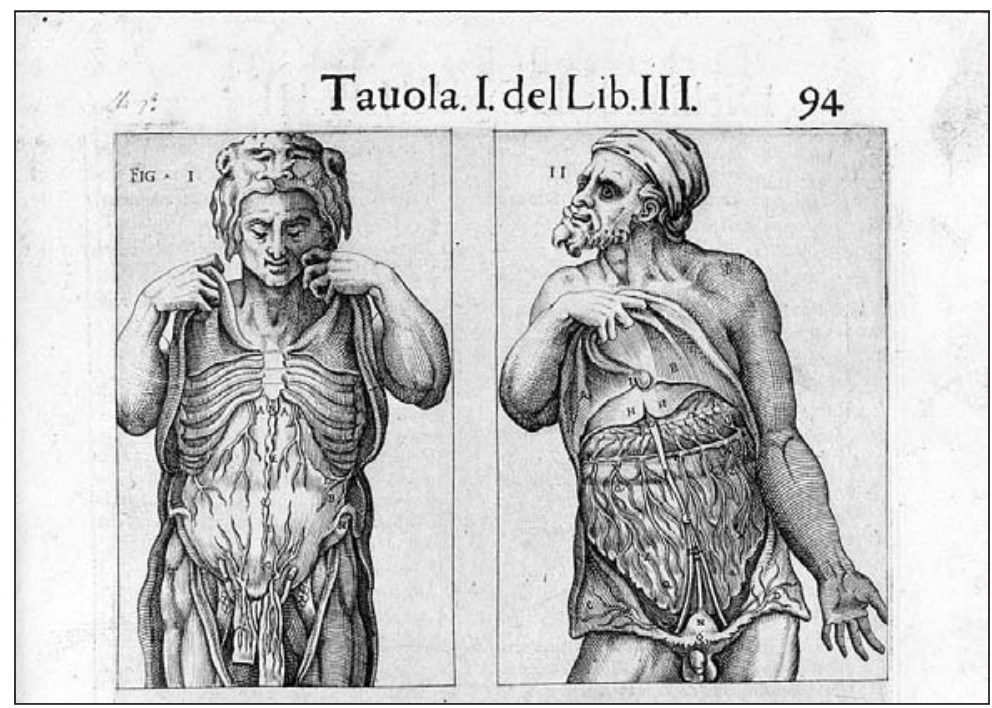

Figure 4. Juan de Valverde Humoso, Anatomia del corpo humano (I556). Credit: By Permission of the Folger Shakespeare Library.

mist's role, he fails to reconstitute the body politic, either as a consoling imaginative fabrication of his own weakened mind or in actual political fact. Forgoing his explorative, interrogative stance, his increasingly futile curses, commands, and fantasies settle into the pathos of his final reconciliation with Cordelia. After her hanging, Lear's echoing howls, and the "desperate" deaths of Regan and Goneril (5.3.267), readers and spectators are left to ponder Lear - "unaccommodated man" - surrounded by his progeny, "dead as earth" (5.3.234). ${ }^{37}$

The death of this royal family signals not merely a personal tragedy but, as is widely acknowledged (almost to the point of cliché), the destruction of the body politic. From E. M. Tillyard to Michel Foucault, scholars of the early modern period have demonstrated the prevalence of the "organic political analogy" which "conceived of social structure and process through the prism of the human body." ${ }^{38}$ Increasingly, scholars also have explored the extent to which the spatial concept of the body politic implies and is supported by a number of other figures, including those of territory and the patriarchal family. ${ }^{39}$ In political and medical tracts, theology and sermons, stageplays and poetry, the constellated relations among the body, monarch, family, land, and kingdom lead to their repeated analogizing of one another. Nowhere is this logic of resemblance and metonymy more cogently put to use than in King Lear. By dividing 
his realm, Lear, Francis Barker argues, simultaneously "disarticulates the order of the family," contravening those "necessary bonds of nature" that in a monarchy support "the political anatomy of the king's body." Body, family, land, ruler, and the corpus politicum so substantially interrelate and imply one another that, Barker argues, "It is with the same gesture of division that Lear fissures his kingdom, his family and his reason." 40 Countless critics have concurred with this assessment that "the spring of the entire tragic action, or at least of the Lear plot, is seen to be in the division of the kingdom as such." 41

Contesting this critical commonplace, Richard Strier has defended Lear's original plan of division through an exegesis of the dramatic dynamics of the opening act. ${ }^{42}$ What this critical debate about Lear's motives fails to consider, however, is that its assessment of Lear's madness or reason depends on a prior representational system composed of spatialized figures susceptible to the procedures of anatomy and cartography. Body, family, land, monarch, monarchy: each entity, linked through correspondence, is subject to associated and accretive acts of division. The Fool intimates how the fragmentation of one figure will entail the destruction of another when, in his own didactic demonstration of the foolishness of Lear's abdication, he conjures the image of an egg, "clove[n] . . i i'th' middle," likens this split egg to Lear's divided royal "golden crown" and his aged "bald crown" (1.4.130-31), and then, by comparing both broken crowns to Lear's "pared wit," describes Goneril as "one o' the parings" (1.4.151-54). With Lear's rebellious daughter now in possession of half the kingdom, the Fool's trenchant parable adumbrates how the king's division of his realm will rebound on his own head. This lesson is reiterated and intensified when, as the play nears its climax, Lear himself tropes on the macabre image of his dual and divided crown to signify the loss of his wits: "Let me have surgeons," he calls, "I am cut to th' brains" (4.5.183-84) [See Figure 5].

The Fool's anatomy of Lear's pared wit allegorizes the play's insistence that land and body, kingdom and family, are part and parcel of a spatial epistemology. Much of the play's tragic force is derived from exploiting the dramatic potential of this interactive chain of signification, whereby the play's central tropes - body, kingdom, crown, eyes, and brain (and with them, life, power, authority, sight, and rationality) are continually spatialized, dissected, and partitioned. The complex intertwining of these tropes amplifies their power of allusion, moving the play inexorably toward tragedy, as the cumulative effects of their fragmentation transit across the figurative landscape. The many critics who concur that in one fell swoop Lear destroys his kingdom, his fam- 


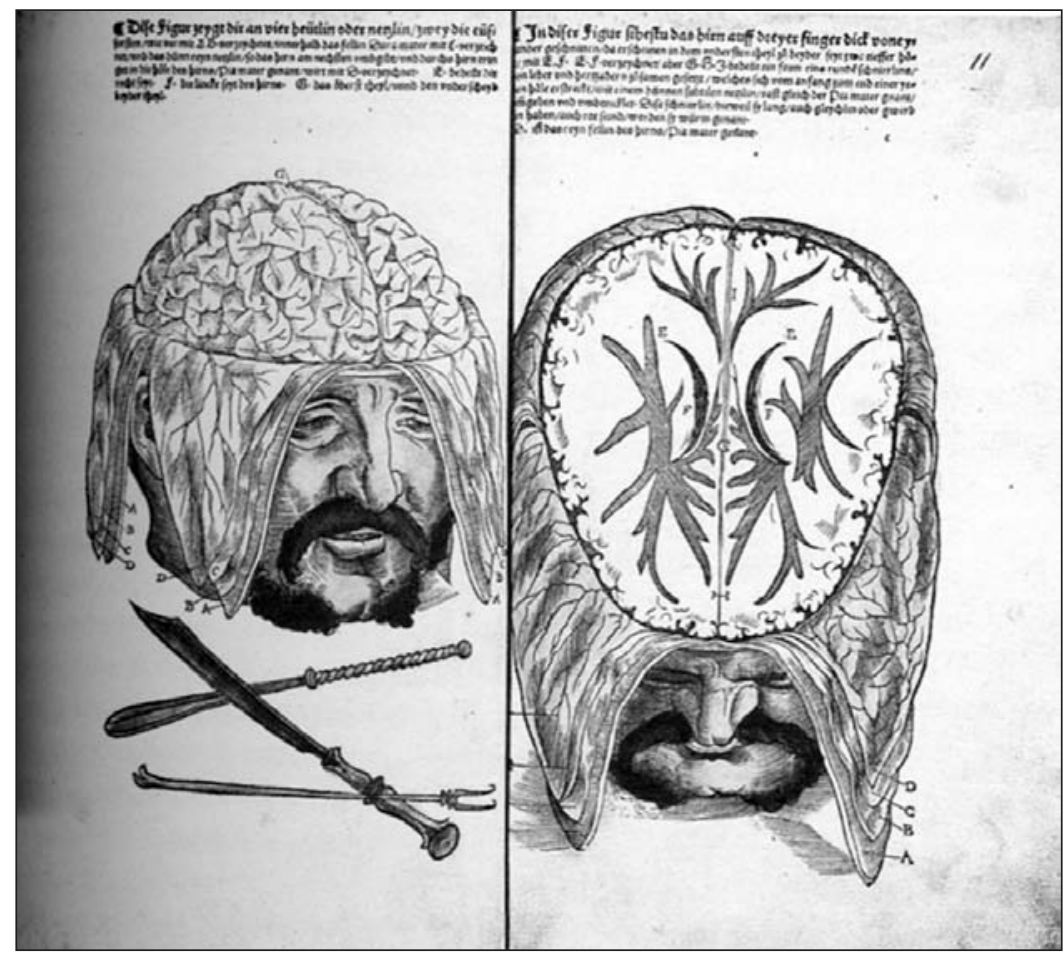

Figure 5. Hans Baldung Grien, Removal of the Pia Mater; Cross-Section of the Brain, Tabulae Decem ( I54I). Credit: Philadelphia Museum of Art: Purchased with the SmithKline Beckman Corporation Fund, 1982.

ily, and his mind are themselves subject to the magnetism of a spatial logic that pervades the play, as well as early modern culture. Thus, it is not simply a mutual reliance on a discourse of discovery or their common practices of division and fragmentation that unite and redouble the impact of anatomy and cartography in King Lear. From "Give me the map there" to "let them anatomize Regan," the play's cartographic logic morphs into an anatomical one, creating a powerfully allusive and alluring spatial style of reasoning.

Awareness of the correlation between anatomy and cartography, along with ready recourse to the land-body-body politic analogy, risks, however, naturalizing both ideology and literature. That is, by treating both 
sets of correspondence as distinct modes of explanation sufficient unto themselves, we tend to ignore their interrelationship as well as the productive material consequences of scientific technologies and discourses which drew from, exploited, and contributed to it. In the larger project of which this essay is a part, I argue that the dramatic effects achieved in Lear derive some of their energy and force from the specific representational strategies that early modern anatomical and cartographic practices concurrently cultivated and shared. Through a diachronic intertextual argument, I demonstrate that the circulation and diffusion of western European anatomical illustrations, voyage illustrations, and maps around the end of the sixteenth century - when voyages of discovery, colonization, and trade were occurring at an unprecedented rate-resulted in a new graphic idiom, the spatializing logic of which Lear appropriates, and to which it adds.

In their representation of human bodies, both anatomy and cartography sought to represent how people across vast spans of geography resemble and differ from one another. As Andreas Vesalius wrote in his influential De Humani Corporis Fabrica: "Corpus itaque publicae sectioni adhiberi convenit, in suo sexu quam temperatissimum, et aetatis mediae, ut ad hoc tanquam ad Policleti statua alia corpora possis coferre" "It is desirable that the body employed for public dissection be as intermediate in nature as possible according to its sex and of medium age, so that you may compare other bodies to it, as if to the statue of Policleus"). ${ }^{43}$ Referring to Polykleitos, the antique sculptor who developed a canon of human proportions, Vesalius proposes the purpose of anatomy as the humanist revelation of an ideal measure, and his widely noted use of classical statuary for anatomical models is a logical result of this aim. [See Figure 6].

Thus, while anatomists recognized in the corpses they dissected considerable variations due to age, size, gender, and ethnicity, they negotiated the tension between the untidiness of a dissected corpse and the desire for an ideal type by composing, in the words of medical historian Nancy Sirasi, "a generalised human body, essentially uniform in its fundamental framework." ${ }^{44}$ Whether surrounded by a minimalist rendition of an antique landscape or reduced to a broken piece of classical statuary, the corporeal schema codified by Vesalius is fantastically devoid of disease, irregularity, morbidity, or the marks made on the flesh through the processes of living, labor, and dying.

This imposition of uniformity onto the messiness of the bodily interior means that, even as it attends to specific body parts, anatomy necessarily privileges generality over particularity. Even more indicative of its generalizing aims is a strategy that those scholars who focus on the penetrative 


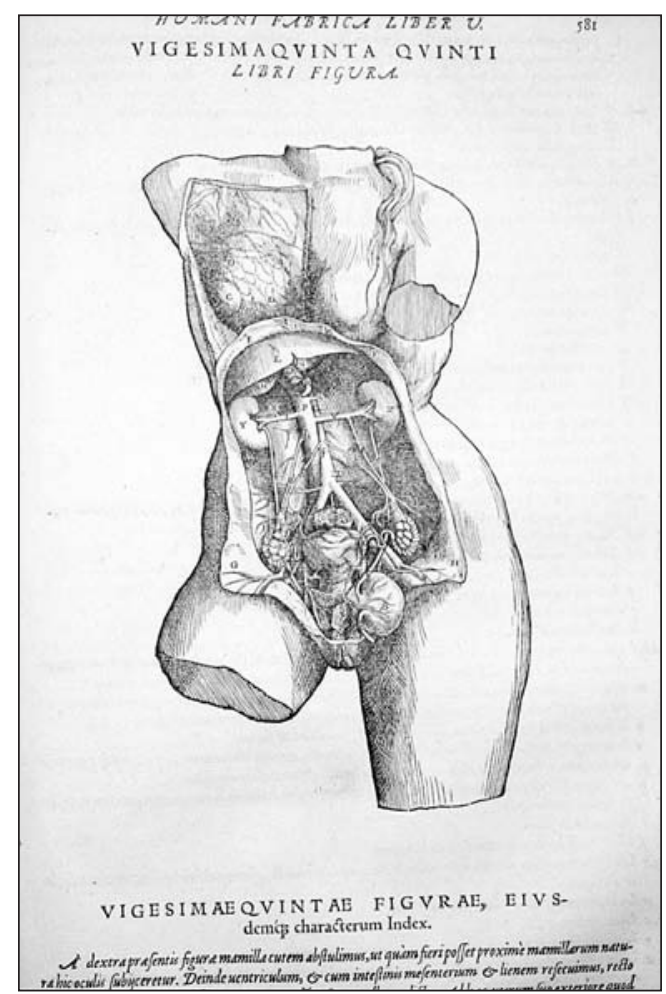

Figure 6. Andreas Vesalius, "Libri Figura," De Humani Corporis Fabrica (I555). Credit: Historical Collection, Eskind Biomedical Library, Vanderbilt University Medical Center.

violence of dissection tend to ignore: anatomy's dependence on spatialized frames of reference for positioning its objects of scrutiny. Here it is less the interior of the body than its exterior, its surface rather than its volume, that comes to the fore: not Vesalius's fragmented antique torsos with their guts spilling out, but his animated "musclemen" (See Figure 2) as well as the images of male and female surface anatomy that grace his Epitome (See Figures 7 and 8). In such figures, we can begin to discern the conceptual effects of specific graphic strategies widely utilized in anatomy: the isolation of a single (or sometimes double) figure, posed against a minimal background, often presented in both anterior and posterior perspective. These strategies, in concert with the use of a consistent scale of measurement and innovative strategies for labeling body parts, forge for anatomical representation a spatialized idiom of bodily abstraction.

Particularly telling in this regard are the forty-seven anatomical plates of Bartholomaeus Eustachius (See Figure 9). Contemporaneous to Vesa- 


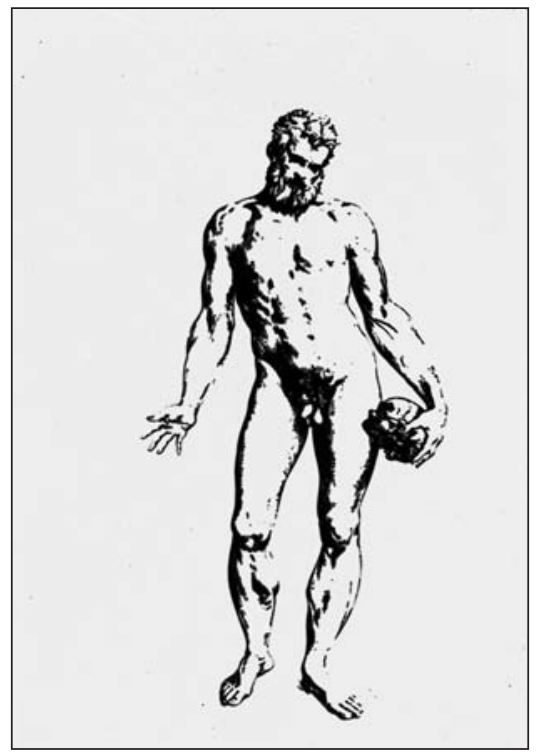

Figure 7. Andreas Vesalius, De Humani Corporis Fabrica Epitome (I543). Credit: Alfred Taubman Medical Library, University of Michigan.

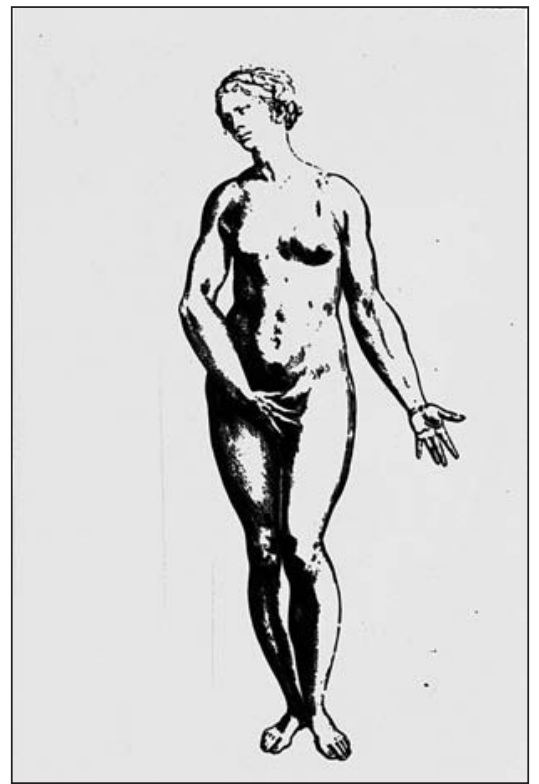

Figure 8. Andreas Vesalius, De Humani Corporis Fabrica Epitome (I 543) Credit: Alfred Taubman Medical Library, University of Michigan. 


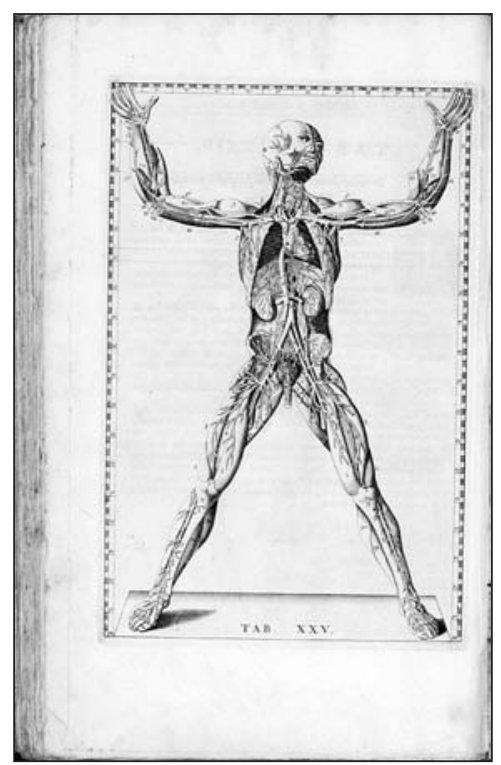

Figure 9. Bartholomaeus Eustachius, "Tabulae XXV,' Tabulae anatomicae classisimi (17|4). Credit: By Permission of the Folger Shakespeare Library.

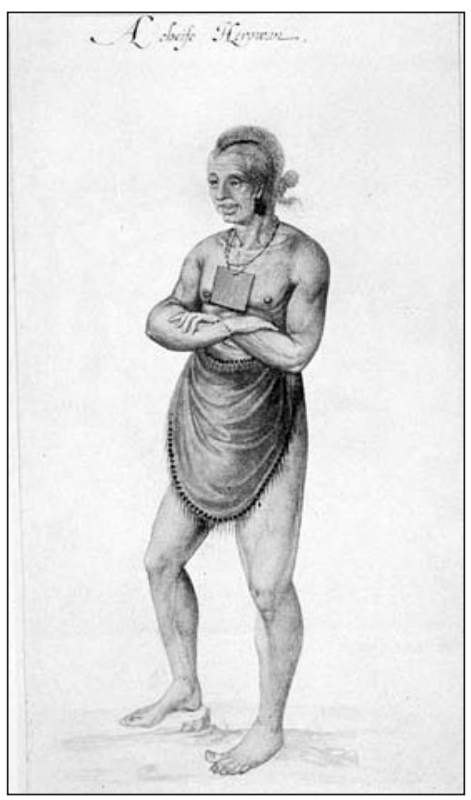

Figure I0. John White, Roanoke chief Wingina ( 1585). Credit: Courtesy The Newberry Library, Chicago and British Museum, London. 
lius, but not published until the eighteenth century, each of Eustachius's figures is placed within an empty rectangular frame, the edges of which are marked off in measurements of five degrees (scales of measurement used within the text to indicate the location of body parts). Using a more schematic and minimalist approach to the human figure than that of the Fabrica, these images were reproduced both with, and without, their gridded borders, even as the grid plate convention was adopted by other anatomists. Eventually superseded by other methods of integrating captions into anatomical engravings, Eustachius's gridded plates nonetheless reveal what other early modern anatomical illustrations imply: that the graphic representation of the anatomical body depends, albeit in most cases invisibly, on a conceptual logic of the grid - a spatial system of measured graticules upon which the body can be laid out and cognitively processed. This spatial logic creates not only a uniform model, but a serviceable ratio, a standard for comparison. Through the combined effects of external spatial gridding and internal spatial uniformity, the anatomical specimen becomes a universalized body, one whose individuality, particularity, and difference are subordinated to the creation of an abstract, common humanity. ${ }^{45}$

The universalizing graphic strategies of anatomical illustrations were appropriated by illustrators on board voyages of exploration and colonization, who regularly depicted "natives" in anterior and posterior views against minimalist backgrounds, using consistent scale and identifying captions (See Figure 10). Their images rapidly were published in popular compendiums of travel voyages such as Theodor de Bry's Grand Voyages (See Figure 11). Concurrently, such images were adopted by cartographers as they ornamented their country, continent, and world maps with human figures. The positioning of these figures in ethnographic inserts and along map borders enabled mapmakers to depict, and to conceptually grapple with, what must have seemed a bewildering array of human bodies and cultures (See Figures 12 and 13). With the contours of the physical body delineated according to specific variables (such as skin color and gender), and national, cultural, and status differences signified through bodies and bodily signifiers such as clothing, the inhabitants of the world were rationally ordered according to the social hierarchies of Western Europe.

Despite their considerable differences, then, anatomy and cartography both crafted a spatialized idiom that rendered newly thinkable a representative conceptual model, a stable secular standard, against which commonalities and differences could be measured. ${ }^{46}$ Whether exposing layers of organs and musculature or the skin color and weaponry of indigenous 


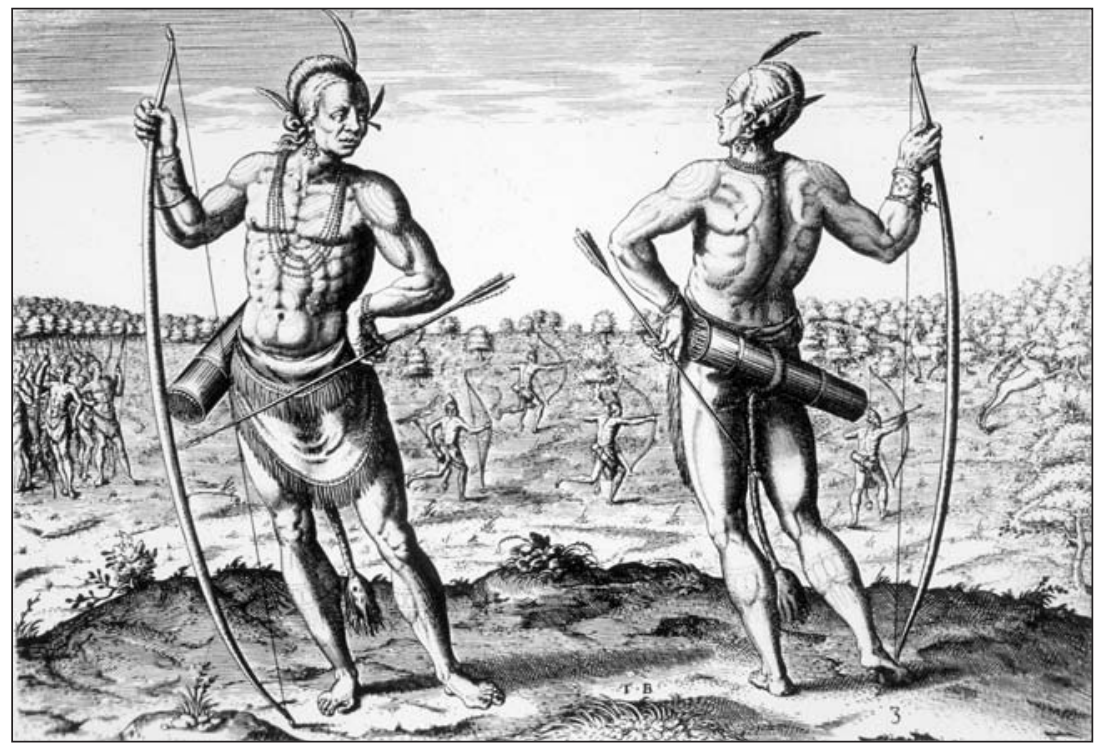

Figure I I.Theodore de Bry, Roanoke chiefWingina, America, Part I (Virginia) ( 1585) Credit: William L. Clements Library, University of Michigan.

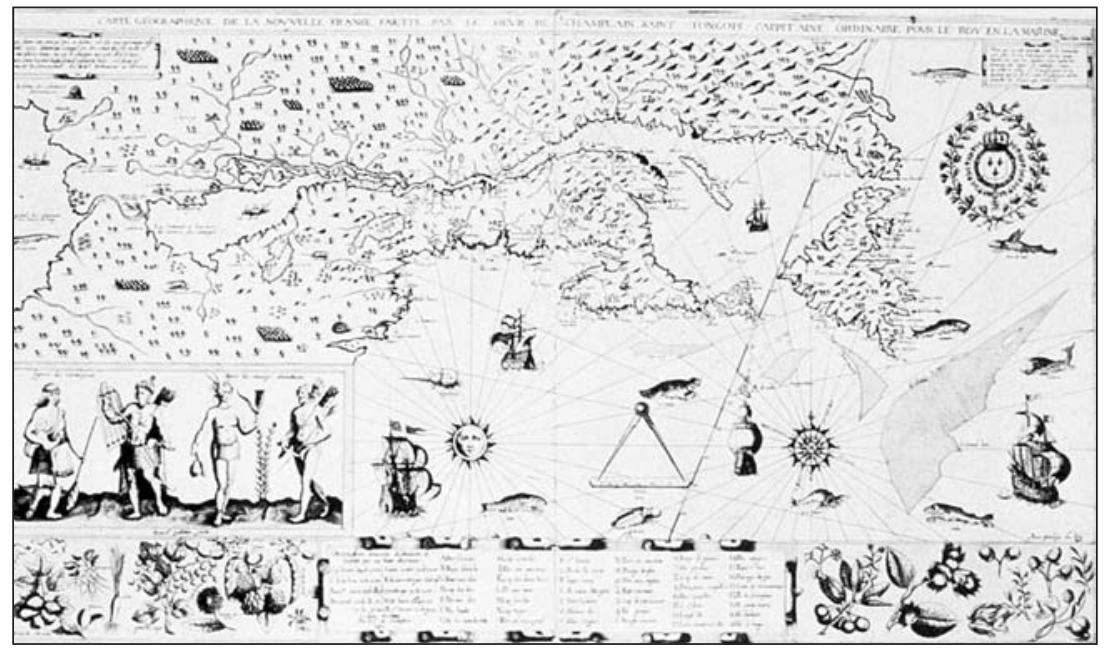

Figure 12. Samuel Champlain, "Carte Geographique de la Nouvelle France" (16 |2) Credit: Courtesy The Newberry Library, Chicago. 


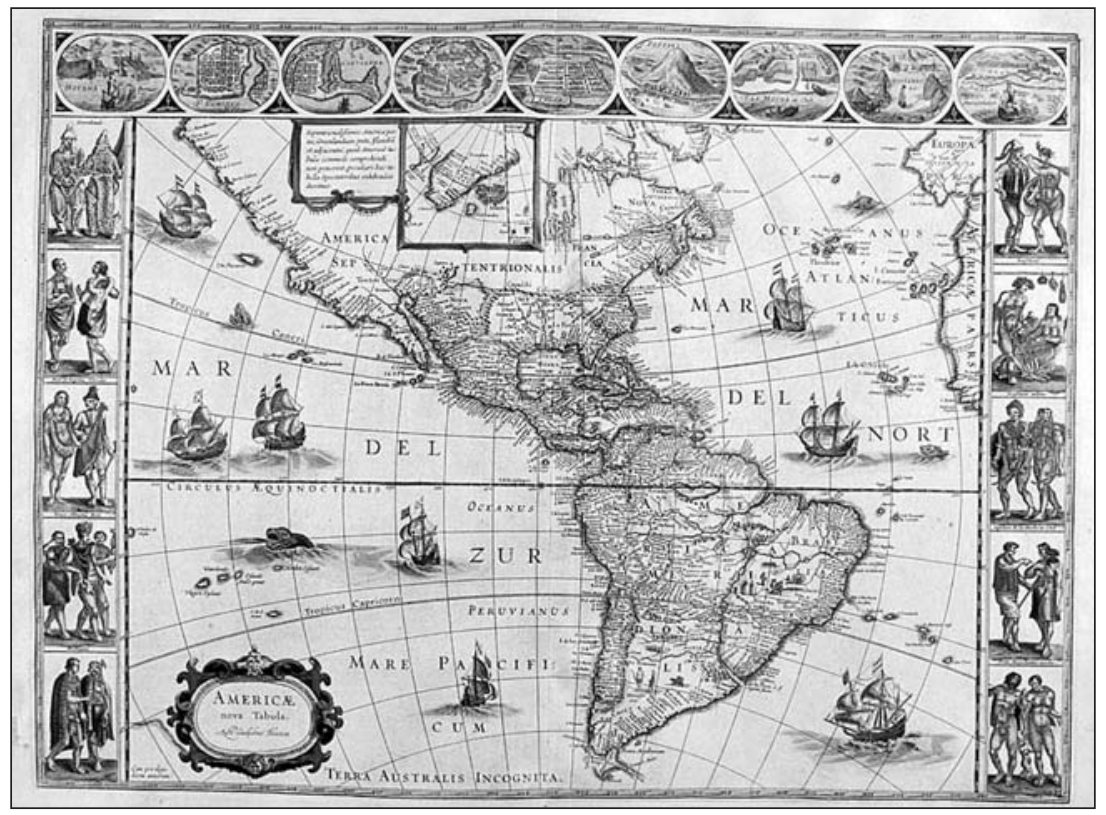

Figure 13. Willem Janszoon Blaeu, "Americae: nova Tabula," Theatre du Monde ( 635/43). Credit: William L. Clements Library, University of Michigan.

inhabitants, anatomy and cartography developed, both separately and in tandem, common spatial techniques of abstraction, rationalization, and comparative classification - in short, systematizing approaches to the diversity of human kind (See Figure 14). Their conceptual and material convergence gave rise to what I call the logic of the grid-a formal, blank, lateral system of signification - which enabled figurative degrees of difference to function as the literal coordinates by which the world's diverse peoples were identified and differentiated, labeled and categorized, classified and compared. Indeed, the synthesis produced by anatomical and cartographic logics eventuated in the construct of a "global" or "new world" body, a corporeal signifier that is simultaneously specific to its geographic locale and metonymic of a larger corporate entity. As a historically contingent manifestation of the logic of the grid, this global body instantiated abstract universalism as an advantageous way to "know" human kind. 


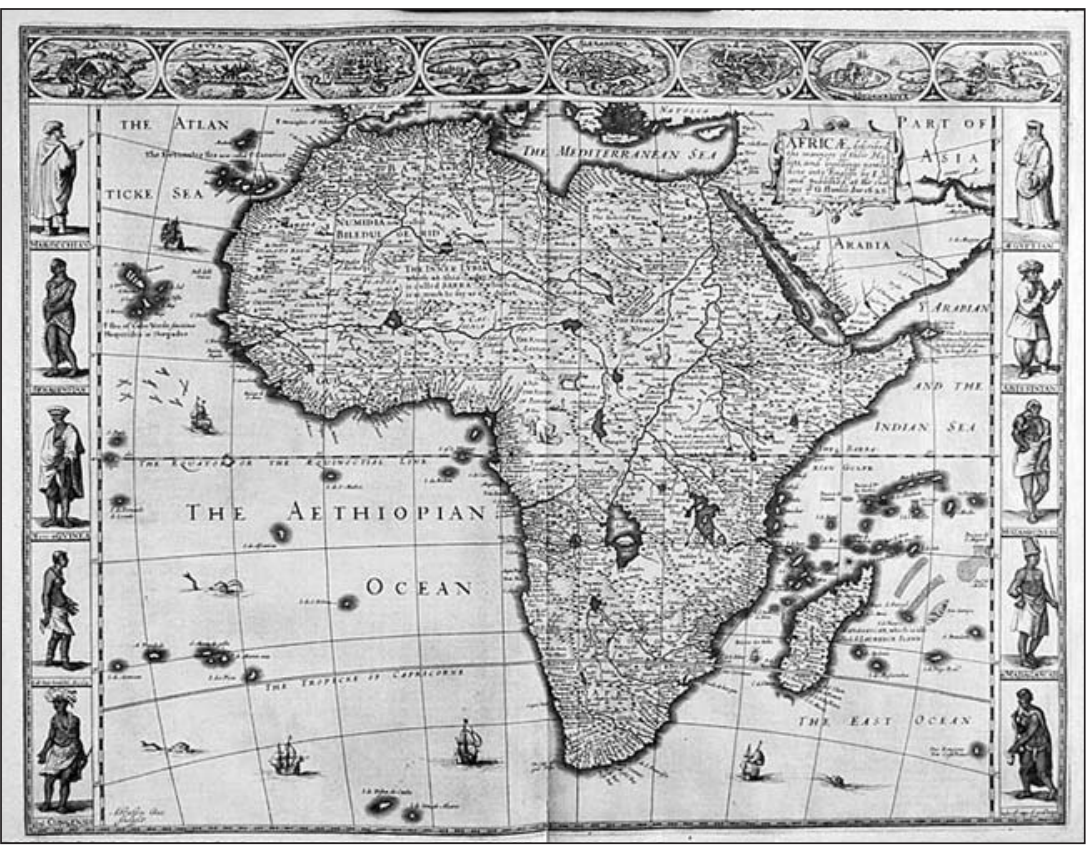

Figure 14. John Speed, "Africae," A Prospect of the most famous parts of the World ( $1627 / 3$ I). Credit: William L. Clements Library, University of Michigan.

While my larger argument depends on a detailed reading of anatomical illustrations, voyage illustrations and maps, my aim here is to suggest that the collusion of anatomic and cartographic tropes in King Lear registers, at the level of what we now call the aesthetic, the historical convergence of anatomy and cartography in creating spatializing treatments of an abstract, representative human body. By adapting for dramatic purposes their confluence and synergy, Lear adopts - at certain textual moments and by means of a temporally unfolding narrative - the strategies of these two sciences for negotiating human commonality and difference.

My concern, however, is not simply to credit the productive interchange between science and literature (what others have called their "creative dialectic" ${ }^{47}$ ), but to explore how Shakespeare's negotiation of the diversity of human kind emerges out of, and in ongoing relation to, a richly metaphoric discourse of nature. Nature: the governing concept organizing the hierarchical order of human, animal, and vegetable life within a Christian cosmos. ${ }^{48}$ It is a concept that, as John Danby pointed out over a half century ago, inundates King Lear ${ }^{49}$ Its consequence was not lost on Raymond Williams, who quotes multiple passages from 
Shakespeare's play in his entry on "nature" in his book Keywords, after calling it "perhaps the most complex word in the language": 50

Allow not nature more than nature needs,

Man's life is cheap as beast's [. . .] (2.2.432)

[...] a daughter

Who redeems nature from the general curse

Which twain have brought her to. (4.5.195-97)

That nature which contemns it origin,

Cannot be bordered certain in itself. (The History of King Lear, Scene 16, 32-3)

[...] all-shaking thunder,

Strike flat the thick rotundity o' th' world,

Crack nature's moulds, all germens spill at once,

That makes ingrateful man [. . . ] (3.2.6-9)

[ . . .] Hear, nature; hear, dear goddess, hear [ . . ] (1.4.239)

With over forty references to nature, natural, unnatural, and disnatured, the play articulates a range of meanings, as Williams summarizes:

nature as the primitive condition before human society [...] an original innocence from which there has been a fall and a curse, requiring redemption [...] a quality of birth, as in the rootword [the Latin nasci, to be born] [...] the forms and moulds of nature which can yet, paradoxically, be destroyed by the natural force of thunder [...] that simple and persistent form of the goddess, Nature herself..$^{51}$

Nature as original condition, intrinsic quality, agency or force, and the physical environment - all of these meanings are brilliantly interwoven in Shakespeare's play, creating a dense texture of allusion that intensifies the distinctions, crucial to the ethical judgments of the play, between the natural and the unnatural. Because of this redoubling of signification, the ambition, lust, and avarice that motivate Lear's two "pelican daughters" (3.4.70), their seemingly unprovoked rebellion against the authority of father and husbands, is generally seen as an attempt to wage war against nature itself - a nature simultaneously moral, social, physical, and supernatural, and which is given intense figural expression in the storm. ${ }^{52}$ In contravening what the play calls the "offices of nature" (2.2.343) in their interlocked manifestations of body, family, monarch, environment, and body politic, the behavior of the play's villains signifies not only a crime against custom, reason, kin, and political order, but the worst of all possible crimes: a crimen contra naturam. 
With a self-conscious medievalism, King Lear intertwines residual and emergent understandings of nature in its effort to saturate this concept with signification. Until the intellectual inroads made by natural philosophy in the seventeenth century, the concept of nature embodied a sacred ideal; nature was assumed to follow reason dictated by the will of God. The motive for invocations of nature was to measure oneself in relation to the divine. Indeed, in medieval literature the goddess Natura functioned as a vicaria Dei, an exalted subordinate of God, a principle of procreation and plenitude as well as moral judge. ${ }^{53}$ The goddess Natura, of course, is only one emanation of this complex concept, for medieval theologians also believed that nature since the Fall had been corrupted by sin (natura lapsa). As Karma Lochrie puts it, "The Nature of medieval theologians was a prelapsarian one that represented all that was good and perfect [.. .] The Fall, however, introduced another nature [.. .] that was not so naturally natural but was instead the result of reason's subversion." ${ }^{54}$ Thus, when medieval theologians invoked nature, they were "appealing to a vertical model of Nature that represents not that which is considered to be the human condition, but that which is anterior to it and hard to achieve." ${ }^{55}$ Over time, the concept of nature expanded to include not only that which was consistent (or at odds) with divine reason (the macrocosmic belief in man's vertical placement between animals and celestial beings), but the classical concept of man as the microcosmic measure of God's creation - so aptly represented in Leonardo da Vinci's study of proportion in the manner of Vitruvius, which illustrates Protagoras's dictum of homo mensura: man as the measure of all things. ${ }^{56}$

By the time of King Lear, each of these axiomatic meanings was being pressured by the new empirical natural philosophy. Even if we no longer countenance Danby's bifurcation of Shakespeare's treatment of nature into two opposing intellectual "camps"- the orthodox party of Hooker, represented by Lear and Cordelia, and the empirical party of Hobbes, articulated by Edmund, Goneril, and Regan-Danby is correct that historically specific, contrasting ideas of nature impart a complexity and capaciousness to the impact of this word in the play. But because nature in King Lear paradoxically is a reflection of the divinely sanctioned hierarchical, patriarchal social order, and an instinctual repulsion from it, it is impossible to settle on its ultimate meaning. ${ }^{57}$

But paradox is not merely the metaphorical ground of Shakespeare's play. Paradox also names the retrospective anticipation that structures the historical situation of King Lear. For, if nature is the conceptual and metaphorical foundation upon which the play's action unfolds, the play's opportunistic use of a logic derived from the synthesis of 
anatomy and cartography suggests that an appeal to something other than nature comprises the play's future aspect. The implications of this proleptic gesture emerge most clearly in Lear's evidentiary encounter with Poor Tom. The distraught king's identification with the Bedlam beggar does not merely enact a momentary engagement with emergent humanist ideals (sometimes thereafter extrapolated to the entire play), nor does its anatomical pedagogy halt at a single object of observation. Their encounter also summons an evaluative, didactic logic- - Is man no more than this? Consider him well" - that forges a lateral comparison between man and man.

Humanism, yes. But to suggest that this resolves the meaning and significance of this logic is to ignore that lateral comparison would also emerge as the constitutive basis of a style of reasoning governed by a concept of norms. ${ }^{58}$ As Lochrie observes, norms "are based on horizontal models of nature that derive from observation, compilation, measurement and comparison. The ideal suggested by the modern norm is, therefore, not anterior but consequent to our evaluation of what is common to most human beings." 59 It is just such a consequential evaluation, involving the capacity to think comparatively along a horizontal axis of differentiation, that Lear's consideration of "man" here performs. This instance of horizontal comparison exists in unresolved tension with the vertical hierarchy implicit in a medieval nature governed by pagan gods, as well as with the reassertion of the patriarchal hierarchy at the play's end. Misrecognized as a triumph of humanist empathy and equality, Lear's didactic anatomy proffers evaluative comparison of human kind as one of the play's primary modes of knowledge and paradigmatic means of judgment.

Evaluative comparison, of course, is not normativity. As a number of scholars have observed, the modern concepts of norms, normality, and normativity, inchoate in the seventeenth-century development of theories of probability and objectivity, ${ }^{60}$ gained traction under the broad project of Enlightenment rationality, as mathematical models were applied to new domains of human experience. ${ }^{61}$ The applicability of the logic of normality became more pervasive over the course of the nineteenth century, as quantifying approaches to human populations (such as demographics, surveys, and statistics - what Ian Hacking calls the "avalanche of numbers") became the primary mode of constituting truth in modern society. ${ }^{62}$ When methods derived from the investigation of statistical averages were adopted in medicine (with its focus on abnormality and pathology), statistical and evaluative norms increasingly were conflated..$^{63}$ The result of this historical process ranges from such 
concepts as the normal curve (popularly known as the "bell curve"), to normal and pathological cells, normal and abnormal psychology, and normal and deviant behavior. ${ }^{64}$

Focused as they are on the merger of quantitative and evaluative criteria, previous histories of normality have tended to treat the knowledge production of the sixteenth and early seventeenth centuries as, at best, hazy precursor formations. Or, when scholars contemplate the premodern era, they have shown how invocations of norms and normativity fail to adequately convey medieval habits of thought. ${ }^{65}$ In addition, although an idiom of nature inflects most analyses of normality and assumptions about norms undergird most analyses of nature, scholars, until now, have neglected to consider why these two concepts so readily imply one another. ${ }^{66} \mathrm{I}$ want to suggest that the convergence of anatomy and cartography in King Lear provides us with some analytical purchase on this question - that is, on the historical nature of norms.

"Is man no more than this?" What, precisely, does Lear at this moment invite us to compare? Having invoked an implicit standard of measurement through the quantifier "more," the play falters in its attempt to measure the meaning and significance of man. ${ }^{67}$ Other than dramatizing Lear's identification with the almost-naked madman and his recognition of "unaccommodation" as humanity's basic condition - "Off, off, you lendings! Come, unbutton here" (3.4.97) (a disrobing quickly countered by the teeth-chattering Fool and Gloucester's appalled insistence on repairing to the hovel) - the play never directly affirms whether man might be "more than this." ${ }^{68}$ In asking us, in reference to the beggar, to "consider him well," Lear points to a corporeal signifier that, despite Poor Tom's verbosity, has been largely hollowed of intelligibility ${ }^{69}$ The epistemological void signified by Poor Tom's blighted body, his "presented nakedness" (2.2.168), and Bedlam speech-foreshadowed in his self-description, "Edgar I nothing am" (2.2.178) — is mirrored in the harsh, minimalist, delocalized landscape upon which their encounter takes place. It is almost as if Lear, at this moment of confrontation, points with the ghostly hand of the anatomist, cadaver, or cartographer to a caption that should name a part of the body or the landscape - but the content of the caption is missing (See Figures 15 and 16).

Lear's humanist point of reference in this anatomical encounter is neither confident nor secure; just as his consideration of Regan's "hardheart" fails to reveal its cause, Poor Tom's anatomical "epitome" resists transcendent meaning. ${ }^{70}$ So too, Lear's map fails to rationally order the kingdom - rather, sociability dissolves, like the landscape in the storm. ${ }^{71}$ Lear's futile appeal to the knowledge that might be attained by anatomy, 


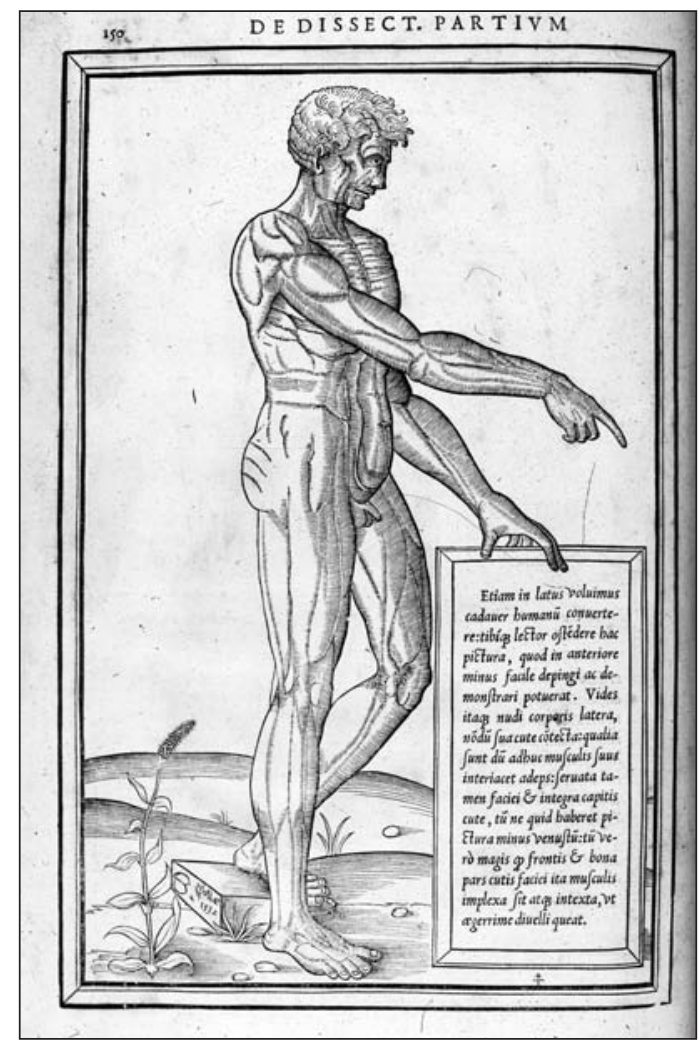

Figure 15. Charles Estienne, "De Dissect. Partivm," La Dissection des Parties du Corps Humain ( 1545). Credit: Rare Book and Manuscript Library, University of Pennsylvania.

measurement, and mapping has much in common with other failed attempts at reason in the play, including the effort to quantify Cordelia's love as something befitting "a third more opulent" portion (1.1.76), and his misrecognition of Goneril's offer of fifty knights as equaling "twice" Regan's "love" (2.2.426). Oscillating uneasily between the "all" and "nothing" that comprise the play's two poles of affect and experience (and ironized in Edmund's self-satisfied query about the increasingly jealous Goneril and Regan - "Which of them shall I take?-Both?-one? - or neither?" [5.2.48-9]), the tragic action descends in the final act to the hollow rotundity of Lear's howls, his agonizingly human hope for the feel and sight of Cordelia's breath, and the pathos of his concluding confrontation with finitude: "never, never, never, never, never" (5.3.283).

Neither anatomy nor cartography bring order or meaning to Lear's world. In emphasizing anatomy's complicity with cartography, I have 


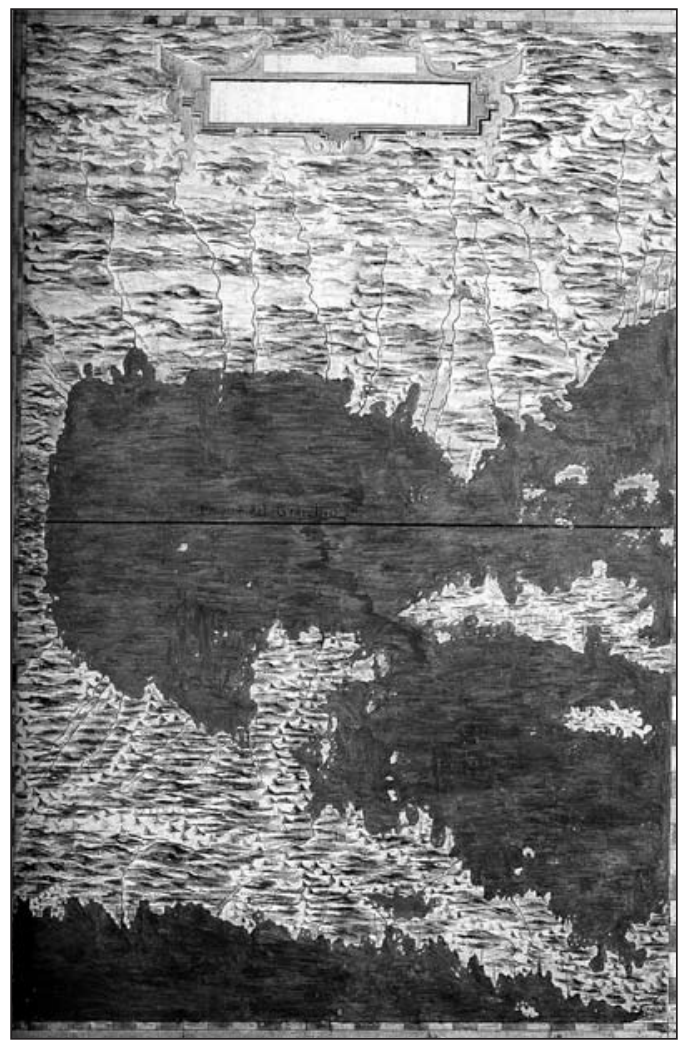

Figure I6. Egnazio Danti, "Mexico, Florida, Cuba e Jamaica” (I565), Guardaroba Nuova, Palazzo Vecchio. Credit: With permission of Musei Comunali di Firenze.

attempted to push others' critical insights regarding the disastrous inadequacies in King Lear of rationalizing systems of thought in a slightly different direction - not toward early modern literature's assessment of early modern measurement, quantification, mapping, and anatomy, but toward a future style of reasoning anticipated by both science and literature. By replacing the all-too-silent gods with human points of comparison; by troubling the self-evidence of the vertical social hierarchy with a momentary horizontal mode of assessment; but most of all, by confronting the emptiness of signification conveyed by Poor Tom's "presented nakedness," the play supplements, and to a certain extent supplants, its densely allusive discourse of nature with a logic akin to that which, at the same historical moment, was being produced by the interaction of anatomy and cartography. To this extent, King Lear partakes, if only momentarily, in the logic of the grid, that lateral system of 
signification which enables us to identify, classify and compare diverse phenomena of the natural world, including human kinds. ${ }^{72}$ In so doing, the play pushes beyond the field of signification summed up by natura into new conceptual territory, where in due time the Renaissance "discovery" and celebration of the individual would be overtaken by and incorporated into the Enlightenment goal of a global taxonomy of the world's population.

The concept of an abstract, universal, representative human-what we now tend to think of as a normal human - is the product of specific styles of reasoning grounded in, and made possible by, contingent material practices: art as well as science. In its seamless conjoining of the logics of anatomy and cartography, King Lear is implicated in, helps give rise to, and provides support for nascent understandings of an alternative universal, the terminology and appeal of which would become dominant only much later in time. From the prospect provided by Lear as it gestures fitfully toward the future, we can begin to see how nature and norms may have first begun to interact: not through attempts to govern and discipline bodily conduct, but by virtue of a style of reasoning whose epistemology is spatial and committed to abstraction rather than prescriptive and particularizing. Lear's anatomico-cartographic encounters with Poor Tom and with Regan's "hard heart" are incipient, "failed," yet exceptionally affecting instances of this style of reasoning in the making.

$$
* * *
$$

Insofar as King Lear appropriated an emerging mode of rationality for a drama of irrationality writ large, its engagement with anatomy and cartography was brilliantly productive of literary form. ${ }^{73}$ Yet, I hope to have shown that the ramifications of Lear's aesthetic productivity extend beyond its exposure of the limitations of early modern science. If the universalizing, comparative, spatial logic of anatomy and cartography infiltrated domains of thought generally perceived to be independent of them, what were its specific effects vis-à-vis the literary and dramatic aesthetic? To answer this question, I turn, in closing, to the implications of this style of reasoning on some enduring appraisals of the literary and dramatic merits of King Lear.

Since the nineteenth century, the status of King Lear as Shakespeare's masterpiece has hinged on its treatment of human nature. ${ }^{74}$ This derives from the fact that since Samuel Johnson's influential preface to his edition of the plays, nature has served as the foundation of the poet's claim to greatness: 
Nothing can please many, and please long, but just representations of general nature [.. .] Shakespeare is above all writers, at least above all modern writers, the poet of nature; the poet that holds up to his readers a faithful mirror of manners and of life. His characters are not modified by the customs of particular places, unpracticed by the rest of the world; by the peculiarities of studies or professions, which can operate but upon small numbers; or by the accidents of transient fashions or temporary opinions: they are the genuine progeny of common humanity, such as the world will always supply and observation will always find. His persons act and speak by the influence of those general passions and principles by which all minds are agitated, and the whole system of life is continued in motion. In the writings of other poets a character is too often an individual; in those of Shakespeare it is commonly a species. ${ }^{75}$

Johnson's neoclassical appraisal of Shakespeare as "the poet of nature" generally has been taken either as a faithful description of the source of Shakespeare's universality or, increasingly, as an ideological mystification of it. Yet, even those critics who would insist on the particularity and cultural embeddedness of Shakespearean plots, images, and characters neglect to consider that Johnson's invocation of a universal human nature also articulates the style of reasoning, avant le lettre, that assumes that nature is manifested through social norms. In all but the word, Johnson's "poet of nature" functions as an agent and avatar of the normal: Shakespeare offers "just representations" of those members of a "species" who are themselves representative of that species; it is through their "general passions and principles" that a "whole system of life" is reproduced; that system of life implicitly is a universal one. The assertion of Shakespeare's universality, then, depends on an ontological assertion of human nature as "common humanity" - itself an avatar of the normal. In other words, Johnson's description of Shakespeare's transhistorical aesthetic merit silently enacts a conceptual slide from an early modern version of a universal human nature to the modern conception of a universal norm. ${ }^{76}$ Functioning as a bridge between these two styles of reasoning, his neoclassical aesthetic of universality becomes intelligible as one more link in the genealogy I have been tracing.

The pervasive pull of abstract universalism in aesthetic appraisals of Shakespeare's "greatest tragedy" likewise gives us an angle from which to reassess the critical controversy that long attended the play's performance history. Despite its status as Shakespeare's greatest play, Lear was for many years judged as one of his least performable. The catastrophic moral 
and epistemological questions the play poses and refuses to answer; the immense psychic landscape, including the extremes of mental anguish, it traverses; its vagueness of time and locale; the brute violence visited on aged and thus profoundly vulnerable bodies - all of these reference an imaginative reality that, according to many critics, is incommensurate with stage representation. As A. C. Bradley put it a century ago: "The stage is the test of strictly dramatic quality, and King Lear is too huge for the stage." ${ }^{77}$ Whether, as more recent critics argue, this judgment has been countered by "a succession of brilliant stage performances" 78 - as well as, one might add, cinematic ones-Bradley's reasoning is worth reexamining, for it indirectly alludes to the impact of abstract universalism on theatrical representation. If performance scholars rightly insist that bodies on stage move against abstraction, it is still the case that the appeal to universality remains an implicit criterion by which embodied performances are judged.

After detailing the many ways in which the play is "imperfectly dramatic," "79 Bradley asks "How is it, now, that this defective drama so overpowers us that we are either unconscious of its blemishes or regard them as almost irrelevant?" The answer, says Bradley, is "that feeling which haunts us in King Lear, as though we were witnessing something universal - a conflict not so much of particular persons as of the powers of good and evil in the world." 80 This answer leads directly to the anatomizing of human nature:

How can there be such men and women? [. . .] How comes it that humanity can take such absolutely opposite forms? And, in particular, to what omission of elements which should be present in human nature, or, if there is no omission, to what distortion of these elements is it due that such beings as some of these come to exist? [. . . 'Then let them anatomise Regan, see what breeds about her heart. Is there any cause in nature that makes these hard hearts?'- the strain of thought which appears here seems to be present in some degree throughout the play. We seem to trace [...] the tendency of imagination to analyse and abstract, to decompose human nature into its constituent factors, and then to construct beings in whom one or more of these factors is absent or atrophied or only incipient. ${ }^{81}$

The concept of a universal human nature by which one can compare "humanity" to itself (in order to assess its "absolutely opposite forms") calls forth the poet's ability "to analyse and abstract," to "decompose human nature" and then, through the imaginative work of character, to 
recompose it. Bradley's evaluative language of what should be present in human nature is rendered only by reference to its distortion or omission, its absence or atrophy; thus, it is hardly surprising that the following paragraph turns to "the idea of monstrosity" in King Lear: "of beings, actions, states of mind, which appear not only abnormal, but absolutely contrary to nature." ${ }^{82}$ King Lear not only explicitly thematizes the process of decomposition and recomposition identified by Bradley, but gestures toward the normalizing logic that informs Bradley's comparative vocabulary of the abnormal, and which gains support from the older vocabulary of the unnatural. That the play employs an anatomico-cartographic idiom to enact this logic enables us to perceive the contingent ground from which this style of reasoning emerged and to which it still owes considerable allegiance.

\section{$* * *$}

The anatomizing "strain of thought" that allows us to apprehend both "human nature" and that which is "contrary to nature" names the style of reasoning that subtends both Shakespeare's play and many critical appraisals of it. Appropriating the method of anatomy on behalf of the aesthetic, Hodges maintains that "Like all forms of representation, drama fragments and reduces the most extreme and absolute of human experiences in order to represent them." ${ }^{83}$ I hope to have shown that such a universalizing of the "anatomy" performed by the aesthetic is precisely what demands historicizing. At the very least, considering Lear's universalism as historically contingent goes some way toward explaining why critics of contrasting hermeneutic orientations - humanist and feminist, historicist and psychoanalytic, textual and performance-oriented - might all affirm Danby's arresting vision that, in the sorrowful pieta at the end of the play, "all we can see is stricken Humanity holding murdered Nature in its arms."

A rationalizing, comparative, universalizing logic is not always already present in early modern thought - nor is it static, coherent, and unchanging. If, as I argue more fully elsewhere, anatomical and cartographic representation provided one material basis for the abstract universalism that underlies the concept of norms, here I suggest that King Lear helps us ascertain by which affective and dramatic means that style of reasoning gained such persuasive force. The tension between a logic of nature and a logic of norms was just beginning to be felt in the early seventeenth century, and it would take centuries for this tension to resolve itself into 
the modern regime of normality. Nonetheless, it is from the horizon of possibility provided by Lear that we can apprehend the enlisting of the moral residue and suasions of nature, the incorporation and reanimation of its vestigial traces, in the service of a modern - empirical, comparative, and evaluative - style of reasoning. It is to trace the emergence of this style of reasoning that I have minimized the mimetic treatment of literary tropes and themes in Lear in order to decipher, beyond what the play says about maps and anatomies or even how it represents them, its appropriation of their strategies and logics. Shifting from the mimetic to the epistemological, I have sought in King Lear traces of the historical process that contributed to the formation of one of our most potent keywords.

My assertion of a proleptic gesture on the part of Lear simultaneously reenacts and attempts to gain analytical leverage on an intractable challenge facing any historicizing project which seeks to relate the past to the present. As Margreta de Grazia has argued, "seeing the Renaissance as the Early-Now commits itself to the very universalizing tendency that historicizing set out to avoid in the first place." ${ }^{84}$ Nonetheless, our own ideological capture within that "universalizing tendency" is precisely my point - for it is not at all clear how we might exit from the generalizing, abstract standards to which the regime of normality, historically produced, in part, by means of an aesthetic of universality, submits us. Whether we are claiming the early modern as, despite our best intentions, the Early-Now, or arguing that Shakespeare's "works are shaped as much by the pressure of futurity as they are by the world from which they sprang 400 years ago, ${ }^{85}$ such universalism remains an epistemological structure within which many readers and critics of Shakespeare remain caught.

Lear's role in helping us to excavate and reassess the nature of norms is not offered primarily as a testimony to Shakespeare's brilliance and perspicuity. Nor is it necessarily consoling to discover the present (the good, the bad, and the ugly) existing within the temporal fold of the early modern. The genealogy I offer here is more modest than either such claims: exposing what may have been at stake in the historical relationship between nature and norms, as well as how their interaction may have imperceptibly pressured critical appraisals of the poet and the play ${ }^{86}$ Rather than temporally map the concept of "the normal" onto the Renaissance, I have, in de Grazia's words, focused on imagining "both the effort and the cost once involved in preparing the way for it." ${ }^{87} \mathrm{King}$ Lear bequeaths to us the terms of abstract universal humanity-a discourse of normality infused with and bolstered by appeals to our common 
nature - by which we still judge the play, and each other. The "effort and the cost," however we might calculate them, remain ours.

\section{NOTES}

1. I thank Carla Mazzio for her patience, editorial brilliance and faith; Barbara Hodgdon, Peggy McCracken and Cathy Sanok for their careful, informed, generous reading; Annamarie Jagose for her careful listening; and Ari Friedlander, Marjorie Rubright and Stephen Spiess for their valuable research assistance.

2. Michael Warner, The Trouble With Normal: Sex, Politics, and the Ethics of Queer Life (Cambridge, MA: Harvard University Press, 1999), 53.

3. John F. Danby, Shakespeare's Doctrine of Nature: A Study of King Lear (London: Faber and Faber, 1949), 175.

4. 3.6.31-3. Unless otherwise noted, I have used The Tragedy of King Lear (folio version) as published in The Norton Shakespeare, based on the Oxford edition, ed. Stephen Greenblatt, Walter Cohen, Jean Howard, and Katherine Eisamen Maus (New York: Norton, 1997). In The History of King Lear, the question is posed as: "Is there any cause in nature that makes this hardness?"

5. One might compare, for instance, Alexander Leggatt's "The question about Regan becomes a question about human nature. And it remains a question" (King Lear: Harvester New Critical Introductions to Shakespeare [Hertfordshire: Harvester Wheatsheaf, 1988], 19) to Catherine Belsey's assertion in "The Divided Tragic Hero," A Companion to Shakespeare's Works, Vol. 1, The Tragedies, eds. Richard Dutton and Jean E. Howard (Oxford: Blackwell, 2003), 73-94: "Lear is condemning his daughter to the practice of dissection carried out in the contemporary anatomy theatres" (73).

6. David Hillman, Shakespeare's Entrails: Belief, Scepticism and the Interior of the Body (Palgrave MacMillan, 2007), 131.

7. Christian Billing, "Modelling the anatomy theatre and the indoor hall theatre: Dissection on the stages of early modern London," Early Modern Literary Studies 13 (April 2004), 1-17; Hillary M. Nunn, Staging Anatomies: Dissection and Spectacle in Early Stuart Tragedy (Aldershot and Burlington, VT: Ashgate, 2005).

8. Hillman, Shakespeare's Entrails.

9. Michael Neill, Issues of Death: Mortality and Identity in English Renaissance Tragedy (Oxford: Clarendon Press, 1997), 135. On anatomical tropes in Renaissance literature, see also Nancy Vickers, "Diana Described: Scattered Woman and Scattered Rhyme," Critical Inquiry 8 (1981): 265-79, and "“The blazon of sweet beauty's best': Shakespeare's Lucrece," Shakespeare and the Question of Theory, ed. Patricia Parker and Geoffrey Hartman (New York and London: Methuen, 1985), 95-115; Francis Barker, The Tremulous Private Body: Essays on Subjection (London and New York: Methuen, 1984); Carla Mazzio and David Hillman, eds., The Body in Parts: Fantasies of Corporeality in Early Modern Europe (New York and London: Routledge, 1997); and Richard Sugg, Murder After Death: Literature and Anatomy in Early Modern England (Ithaca and London: Cornell University Press, 2007).

10. Within this critical tradition, the gouging of Gloucester's eyes is not only a sadistic form of torture or a figurative manifestation of the father's blindness, but a cruel vivisection.

11. Jonathan Sawday, The Body Emblazoned: Dissection and the Human Body in Renaissance Culture (London: Routledge, 1995), viii. 
12. Devon Hodges, Renaissance Fictions of Anatomy (Amherst: University of Massachusetts Press, 1985).

13. Hodges, for instance, refers to "The struggle in the play about whether or not the method of anatomy should be conceived as negative or positive" (Renaissance Fictions of Anatomy, 76); Hillman argues against seeing early modern drama and anatomy as "simply analogous," in large part because drama constitutes "a powerful critique" of anatomy (Shakespeare's Entrails, 43).

14. Michael Neill, “'The Exact Map or Discovery of Human Affairs': Shakespeare and the Plotting of History," Putting History to the Question: Power, Politics and Society in English Renaissance Drama (New York: Columbia University Press, 2000), 373-97; Garrett Sullivan, The Drama of Landscape: Land, Property, and Social Relations on the Early Modern Stage (Stanford: Stanford University Press, 1998); Richard Helgerson, Forms of Nationhood: The Elizabethan Writing of England (Chicago: University of Chicago Press, 1992); Rhonda L. Sanford, Maps and Memory in Early Modern England: A Sense of Place (New York: Palgrave, 2002).

15. Richard Helgerson and Joanne Woolway Grenfell, eds., "Literature and Geography" special issue, Early Modern Literary Studies 4.2 (1998); Bernhard Klein, Maps and the Writing of Space in Early Modern England and Ireland (Basingstoke: Palgrave, 2001); Andrew Gordon and Bernhard Klein, eds., Literature, Mapping, and the Politics of Space in Early Modern Britain (Cambridge: Cambridge University Press, 2001).

16. John Gillies, Shakespeare and the Geography of Difference (Cambridge: Cambridge University Press, 1994).

17. Gavin Hollis, "'Give me the map there': King Lear and Cartographic Literacy in Early Modern England," The Portolan 68 (2007): 8-25; Peter Holland, "Mapping Shakespeare's Britain," Shakespeare's Histories and Counter-Histories, eds., Dermot Cavanagh, Stuart Hampton-Reeves, Stephen Longstaffe (Manchester and New York: Manchester University Press, 2006), 198-218; John Gillies, "The Scene of Cartography in King Lear," in Gordon and Klein, Literature, Mapping, and the Politics of Space in Early Modern Britain, 109-37; Henry S. Turner, "King Lear Without: The Heath," Renaissance Drama 28 (1999): 161-93; Frederic T. Flahiff, "Lear's Map," Cahiers Elisabethains 30 (1986): 17-33; Terence Hawkes, "Lear's Maps," Meaning by Shakespeare (London and New York: Routledge, 1992), 121-40; Jerry Brotton, "Tragedy and Geography," in $A$ Companion to Shakespeare's Works, Vol. 1, The Tragedies, 217-40; Francis Barker, "The Information of the Absolute," The Culture of Violence: Essays on Tragedy and History (Manchester: Manchester University Press, 1993), 3-92.

18. John Gillies, "Introduction: Elizabethan Drama and the Cartographizations of Space," in John Gillies and Virginia Mason Vaughan, eds., Playing the Globe: Genre and Geography in English Renaissance Drama (Cranbury, New Jersey and London: Associate University Presses, 1998), 19-45, citation p. 33. In relating the division of land to the love test, Gillies calls Lear a "manic cartographer," who demonstrates "the dangers of early modern cartography" ("The Scene of Cartography in King Lear," 117).

19. Gillies, "Introduction," Playing the Globe, 32. Philip Armstrong argues that King Lear is the "prime example" of cartography's "critical influence upon the rhetoric and dramaturgy of Shakespearean theater," whereby "the political and phenomenal world" are reduced "to a cartographic representation," in "Spheres of Influence: Cartography and the Gaze in Shakespearean Tragedy and History," Shakespeare Studies 23 (1995): 39-70, citation p. 40. In "The Scene of Cartography in King Lear," Gillies counters with the suggestion that the perspectivalism of the Dover cliff scene challenges the prestige 
of cartography by means of its more dramatically responsive, phenomenological spatial practice. Gillies makes similar points about Lear in his Introduction to Playing the Globe. Likewise, in "Gelded Continents and Plenteous Rivers: Cartography as Rhetoric in Shakespeare," Playing the Globe, 46-62, Bruce Avery argues that plays and maps have "radically antagonistic formal properties," and that staged drama, particularly Lear, destabilizes the monocular perspective of cartography (47). Rather than reinforcing cartographic values, Lear's map is "a failed attempt at coercive cartography" (53). So too, in The Drama of Landscape, Garrett Sullivan argues that Lear "reveals the inadequacies of and contradictions within cartographic conceptions of the land" by forcing a wedge between geographic description and mathematical partitioning (109). He comes close to suggesting that the play has it both ways, however, insofar as Lear's map implies, as Francis Barker also argues, "a depopulated landscape" (Sullivan 105). Brotten argues that "King Lear is Shakespeare's most explicit meditation on the ways in which geography can be utilized to intensify tragic action" ("Tragedy and Geography," 229).

20. For an overview, see Howard Marchitello, "Science Studies and English Renaissance Literature," Literature Compass 3.2 (2006): 341-65, who argues that "the separation between science and literature . . . is itself more of a consequence of the emergence of science than its cause" (352). See also Denise Albanese, New Science, New World (Durham: Duke University Press, 1996); Graham L. Hammill, Sexuality and Form: Caravaggio, Marlowe, and Bacon (Chicago and London: University of Chicago Press, 2000); Henry Turner, The English Renaissance Stage: Geometry, Poetics and the Practical Spatial Arts (Oxford: Oxford University Press, 2006); Jessica Wolfe, Humanism, Machinery, and Renaissance Literature (Cambridge: Cambridge University Press, 2004); Paula Blank, Shakespeare and the Mismeasure of Man (Ithaca: Cornell University Press, 2006); and Carla Mazzio, "The Three-Dimensional Self: Geometry, Melancholy, Drama," Arts of Calculation: Quantifying Thought in Early Modern Europe, eds. David Glimp and Michelle Warren (New York: Palgrave, 2004): 39-65.

21. My argument here is perhaps closest to that of Elizabeth Spiller, Science, Reading and Renaissance Literature: The Art of Making Knowledge, 1580-1670 (Cambridge: Cambridge University Press, 2004), who argues that "early modern science is practiced as art" and "imaginative literature provides a form for producing knowledge. Within this framework, literary texts become more than just topical commentaries on new scientific discoveries or intellectually (but not truly scientifically) interesting examples of the cultural work that literature might produce in the face of changing scientific knowledge" (2). We differ, however, to the extent that she aims to show how "literary texts gain substance and intelligibility by being considered instances of early modern knowledge production," and, further, insofar as her main concern is to demonstrate "how early modern science and literature ... share related interests in making as a form of knowledge production" (8, emphases mine).

22. I have been influenced in this regard by Walter Cohen, "The Literature of Empire in the Renaissance," Modern Philology 102.1 (2004): 1-34, who argues that most literary scholarship on early modern empire mistakenly assumes "that the influence of empire on Renaissance literature is to be found exclusively in depictions of empire." This critical "overvaluation" of "mimesis" is countered by Cohen's attempt to identify those formal, "nonrepresentational terms" that register the influence of empire on Renaissance consciousness (6), leading him to argue that "rather than deciphering the ideology of form, we need to understand the form of ideology" (29). In "The Undiscovered Country: Shakespeare and Mercantile Geography," Marxist Shakespeares, eds. Jean E. Howard 
and Scott Cutler Shershow (London and New York: Routledge, 2001), 128-58, Cohen explains that his perspective is "an intermediate one that tries to steer a course between a widely practiced kind of Zeitgeist criticism that would swallow up everything into the thematic preoccupation at hand [...] and a conservative scholarly approach that would confine the impact [...] to indisputable representations and allusions" (154-55).

23. I adopt "style of reasoning" from the history of science and philosophy. See A. C. Crombie, Styles of Scientific Thinking in the European Tradition: the History of Argument and Explanation Especially in the Mathematical and Biomedical Sciences and Arts, 3 Vols. (London: Duckworth, 1994); Ian Hacking, "Language, Truth, Reason," Epistemology: The Big Questions, ed. Linda Martin Alcoff (Malden: Blackwell, 1998), 322-36; and Arnold I. Davidson, The Emergence of Sexuality: Historical Epistemology and the Formation of Concepts (Cambridge, MA: Harvard University Press, 2001).

24. Historical epistemology is a project undertaken by Hacking and Davidson, as well as Lorraine Daston and Peter Galison in Objectivity (New York: Zone Books, 2007). In "Historical Epistemology," Questions of Evidence: Proof, Practice, and Persuasion across the Disciplines, eds., James Chandler, Arnold I. Davidson, and Harry Harootunian (Chicago: University of Chicago Press, 1994), 282-89, Daston defines "historical epistemology" as "the history of the categories that structure our thought, pattern our arguments and proofs, and certify our standards for explanation" (282).

25. Neill, Issues of Death, 44. See also Sawday, The Body Emblazoned, 23-8; 87-9; $95 ; 180$.

26. Hodges, Renaissance Fictions of Anatomy, 74; 75; Armstrong, "Spheres of Influence," 40; 42; and Gillies, "The Scene of Cartography in King Lear," 114; 110. Gillies' argument departs from the argument of his earlier book, which emphasized the discursive parallels between theaters and maps. See also his reference to Hotspur's "dissecting gaze" (58) and the anatomization of the female body in King John (62). Brotton also refers to "the geographical and anatomical discourse of the functional body politic," although his topic is geography, not anatomy ("Tragedy and Geography," 238). In Enter the Body: Women and Representation on Shakespeare's Stage (London and New York: Routledge, 2001), Carol Chillington Rutter moves quickly from "the map of the kingdom" to the "vivisection or grotesque anatomy" demanded by Lear of Cordelia to Lear's attempt to "anatomize Regan" (14-15). References to anatomy crop up throughout Lear criticism. See, for instance, Thomas Clayton, “'Is this the promis'd end?' Revision in the Role of the King," The Division of the Kingdoms: Shakespeare's Two Versions of King Lear, eds., Gary Taylor and Michael Warren (Oxford: Clarendon, 1983), 121-41: "These alterations are part of an evident, emphatic, and functional pattern that combines the progressive peeling away of layers of attire, appearance, affectation, and at last anatomy itself with an ultimate regression (or progression) to a state of 'second childhood"' (122). This critical tradition is anticipated by Charles Lamb, "On the Tragedies of Shakespeare Considered with Reference to their Fitness for Stage Representation" (1811): "A happy ending! — as if the living martyrdom that Lear had gone through, - the flaying of his feelings alive, did not make a fair dismissal from the stage of life the only decorous thing for him" (reprinted in Susan Bruce, ed., William Shakespeare, King Lear [New York: Columbia University Press, 1998], 56).

27. The one exception is Caterina Albano, "Visible Bodies: Cartography and Anatomy," in Literature, Mapping, and the Politics of Space in Early Modern Britain, eds. Gordon and Klein, 89-106, who, through analysis of the body-land analogy, argues that "cartography and anatomy mutually enable each other" (91). Her argument regarding 
their reciprocal relations, however, focuses on "a politics of specialization" (91), based on desire, which "rendered both body and space culturally visible" (104).

28. Gillies says almost as much when he notes that "the 'space' of Lear is defined less by geography than the primal mediacy of the body. From the moment of the map to the 'Dover cliff' scene, the major spatial idea in Lear is built around the bodily opposition of housedness and unhousedness, accommodation and nakedness [. . .] The movement from inside to outside in Lear is accompanied by a stripping and abjection (and consequent foregrounding) of the body" ("The Scene of Cartography in King Lear," $123 ; 124)$. Gillies, however, does not explore the connection between geographical and embodied space, instead pursuing a phenomenological account of the way the social prestige of cartography was trumped in Lear by the dynamic perspectivalism of the stage. Hillman makes clear the extent to which the inside/outside dynamic forms the basis of the play's corporeal imaginary (Shakespeare's Entrails). Since Carolyn F. E. Spurgeon's Shakespeare's Imagery and What It Tells Us (Cambridge: Cambridge University Press, 1935), many critics have emphasized the bodily aspects of the play. In " The Base Shall Top Th' Legitimate': The Bedlam Beggar and the Role of Edgar in King Lear," Shakespeare Quarterly 38 (1987): 426-41, William Carroll argues that "the play's persistent interrogation of the human body's place in the natural and social orders is culminated in Poor Tom's suffering body" (426). See as well Leggatt's introductions to King Lear: Harvester New Critical Introductions to Shakespeare and King Lear: Shakespeare in Performance (Manchester: Manchester University Press, 1991); Greenblatt's introduction to the Norton edition; and Belsey's "The Divided Hero."

29. Brotton, "Tragedy and Geography," 228. As Brotten notes, this locale is "a meaningless area rarely accorded any spatial significance on the kind of maps with which the play begins" (228). See also Hodges, Renaissance Fictions of Anatomy, who refers to the "nonplace" of the heath, 74, and Gillies who refers to its "dissolved" landscape in "The Scene of Cartography in King Lear," 126. In eschewing the term "heath," I follow Henry Turner, who notes that "the heath" appears nowhere in the 1608 Quarto or the 1623 Folio, and is instead a retrospective projection of Nahum Tate's seventeenth-century adaptation and Rowe's 1709 edition, which includes the stage direction "A Heath"; see "King Lear Without" and The English Renaissance Stage, 162.

30. A. C. Bradley, Shakespearean Tragedy (Cleveland and New York: World Publishing Company, 1955 [1904]), 201. Likewise stressing the lack of spatial coherence in the play, Hodges critiques those critics who "wish to place characters in a text that displaces the very idea of place," Renaissance Fictions of Anatomy, 73. Leggatt, King Lear: Shakespeare in Performance, notes that "the lack of detail on Lear's map creates a sense of abstraction, of universality" (3). See also Hollis, "Give me the map there",; Holland, "Mapping Shakespeare's Britain"; and Flahiff, "Lear's Map."

31. According to the OED, "anatomy" was also synonymous with skeleton, a body consisting only of bones or with skin dried to the bones; it also included the notion of a "walking skeleton."

32. See Adriane Stewart, "Body Phantoms: Ontological Instability, Compensation, and Drama in Early Modern England," Ph.D. Dissertation, Vanderbilt University, 1996.

33. The humanist logic that underpins this appraisal was first challenged by Jonathan Dollimore, "King Lear (c. 1605-6) and Essentialist Humanism," Radical Tragedy, 188-203, and quickly followed by David Simpson, "Great things of us forgot: seeing Lear better," Critical Quarterly 28:1\&2 (1987): 15-31. 
34. See, for instance, Leggatt: the "sense that there is something universal and archetypal in the drama is part of the common response to King Lear" (King Lear: Shakespeare in Performance, 3); Leggatt, however, both here and in his Harvester King Lear, links this to "the methods of the morality play" (Shakespeare in Performance, 4). So too G. Wilson Knight, The Wheel of Fire: Interpretations of Shakespearean Tragedy with Three New Essays 4" ${ }^{\text {th }}$ ed. (London: Methuen, 1949 [1930]): "we seem to be confronted, not with certain men and women only, but with mankind. It is strange to find that we have been watching little more than a dozen people [. . .] We watch, not ancient Britons, but humanity; not England, but the world" (177, 178).

35. See, in particular, Danby, Shakespeare's Doctrine of Nature, and Hodges, Renaissance Fictions of Anatomy.

36. Sugg, Murder After Death, 105.

37. The undecidability of the playscript — does Lear die triumphant, blissfully focused with "unbearable joy" on Cordelia's imagined breath (Bradley, Shakespearean Tragedy, 234), or despairing, in full recognition of his loss? - has given rise to multiple interpretations of this final scene, in criticism and on stage and screen.

38. E. M. W. Tillyard, The Elizabethan World Picture (Harmondsworth: Penguin, 1984 [1943]); Michel Foucault, The Order of Things: An Archaeology of the Human Sciences (London: Tavistock, 1970); Jonathan Gil Harris, Foreign Bodies and the Body Politic: Discourses of Social Pathology in Early Modern England (Cambridge: Cambridge University Press, 1998), 1. Gil Harris's unique contribution is to demonstrate the ways in which the organic political analogy became increasingly dysfunctional, as traced through an idiom of pathology.

39. In addition to Barker, Tremulous Private Body, and Dollimore, Radical Tragedy, see Jonathan Goldberg, James I and the Politics of Literature: Jonson, Shakespeare, Donne, and their Contemporaries (Baltimore: Johns Hopkins University Press, 1983); and Louis Adrian Montrose, "The Elizabethan Subject and the Spenserian Text," in Literary Theory/Renaissance Texts, eds., Patricia Parker and David Quint (Baltimore: Johns Hopkins University Press, 1986), 317-31.

40. Barker, Tremulous Private Body, 33.

41. Richard Strier, "Impossible Radicalism II: Shakespeare and Disobedience," Resistant Structures: Particularity, Radicalism, and Renaissance Texts (Berkeley: University of California Press), 177.

42. "What we witness in the opening scene, then, is not a disastrous plan being made yet worse, but a set of spontaneous bad decisions on Lear's part supervening on a plan that might well have been a workable one" (Strier, "Impossible Radicalism II," 180).

43. Andreas Vesalius, De humani corporis fabrica libri septem (Basel: 1543). The translation is taken from the excerpts published as an appendix to C. D. O'Malley, Andreas Vesalius of Brussels, 1514-1564 (Berkeley: University of California Press, 1964), $317 \mathrm{ff}$., 343, with my modification of the translation of "quam temperatissimum" from normal to the less anachronistic intermediate in nature. I wish to thank Cathy Sanok and Basil Duffalo for help with the Latin.

44. Nancy G. Sirasi, "Vesalius and Human Diversity in De Humani Corporis Fabrica," Journal of the Warburg and Courtauld Institutes 57 (1994): 60-88, 62. On the effects of Vesalius's classicism, see also Glenn Harcourt, "Andreas Vesalius and the Anatomy of Antique Sculpture," Representations 17 (1987): 28-61.

45. With female figures in anatomies of this period used to depict only reproductive anatomy, even gender difference is reduced to a supplement to universal man. See 
Valerie Traub, "Gendering Mortality in Early Modern Anatomies," Feminist Readings of Early Modern Culture: Emerging Subjects, eds. Valerie Traub, M. Lindsay Kaplan and Dympna Callaghan (Cambridge University Press, 1996), 44-92.

46. The rationalization of bodily figures on maps mirrors the rationalization of land and space described by historians of cartography as well as by those critics who interpret the meanings of maps in literature. J. B. Harley's influence on the history of cartography is crucial: see the posthumous volume, The New Nature of Maps: Essays in the History of Cartography, ed. Paul Laxton (Baltimore: Johns Hopkins University Press, 2001).

47. Marchitello, "Science Studies and English Renaissance Literature," 341.

48. In addition to Tillyard, see Arthur O. Lovejoy, The Great Chain of Being: A Study of the History of an Idea (Cambridge: Harvard University Press, 1936).

49. Danby, Shakespeare's Doctrine of Nature, 19. Since Danby, who was anticipated by G. Wilson Knight, the most explicit treatment of nature in the play is Mark A. McDonald, Shakespeare's King Lear with The Tempest: The Discovery of Nature and the Recovery of Classical Natural Right (Latham, MD: University Press of America, 2004).

50. Raymond Williams, Keywords: A Vocabulary of Culture and Society (New York: Oxford University Press, 1976), 219. For the links between the Greek phusis, the Latin natura and the English kind, see C. S. Lewis, "Nature," Studies in Words (Cambridge: Cambridge University Press, 1960), 24-74. See also R. G. Collingwood, The Idea of Nature (New York: Oxford University Press, 1945), and Kate Soper, What is Nature? (Oxford: Blackwell, 1995).

51. Williams, Keywords, 222.

52. There are eight references to "unnatural" in King Lear, double that of any other Shakespeare play. It has been the aim of many feminist critics to demonstrate how the play's concept of nature is a social construction which vilifies female agency and desire as unnatural. The first critic to challenge the presumption of a tight fit between patriarchal authority and the order of nature in the play was Katherine McLuskie, "The Patriarchal Bard: Feminist Criticism and Shakespeare: King Lear and Measure for Measure," Political Shakespeare: Essays in Cultural Materialism, eds. Jonathan Dollimore and Alan Sinfield (1985, rpt. 1994), 88-108.

53. George D. Economou, The Goddess Natura in Medieval Literature (Cambridge, MA: Harvard University Press, 1972).

54. Karma Lochrie, Heterosyncrasies: Female Sexuality When Normal Wasn't (Minneapolis and London: University of Minnesota Press, 2005), xxii.

55. Lochrie, Heterosyncrasies, xxii.

56. Leonard Barkan, Nature's Work of Art: The Human Body as Image of the World (New Haven: Yale University Press, 1975).

57. I nonetheless disagree with Kiernan Ryan's assertion in "King Lear," in $A$ Companion to Shakespeare's Works, 375-92, that "natural," among other "chameleon key words of the play change their meaning so often through multiple usage that they cease to signify anything in themselves, becoming opaque and impervious to translation" (387). That they signify multiply does not mean that they signify nothing.

58. I agree with Kent Cartwright when he argues in Theatre and Humanism: English Drama in the Sixteenth Century (Cambridge: Cambridge University Press, 1999) that "Humanist dramaturgy puts feelings and emotions in productive tension with ideas, apothegms, and intellectual certainties, so that what emerges is a complex matrix of experience and understanding" (20). I would simply stress that emotions are put in productive tension with intellectual uncertainties as well. 
59. Lochrie, Heterosynchracies, xxiii.

60. See Lorraine Daston, Classical Probability in the Enlightenment (Princeton: Princeton University Press, 1988); Barbara Shapiro, Probability and Certainty in Seventeenth-Century England (Princeton: Princeton University Press, 1983); Ian Hacking, The Emergence of Probability: A Philosophical Study of Early Ideas about Probability, Induction, and Statistical Inference (Cambridge: Cambridge University Press, 1975).

61. Michel Foucault's genealogies of modern regimes of sexuality, madness, and criminality are crucial; see especially the five operations of normalization in Discipline and Punish: The Birth of the Prison, trans. Alan Sheridan (Harmondsworth: Penguin, 1977), 177-94; The History of Sexuality, Volume 1: An Introduction, trans. Robert Hurley (New York: Random House, 1978); and Abnormal: Lectures at the Collège de France 1974-1975, eds. Valerio Marchetti and Antonella Salomoni, trans. Graham Burchell (New York: Picador, 2003).

62. Ian Hacking, "Biopower and the Avalanche of Printed Numbers," Humanities in Society 5:3/4 (1982): 279-95; and The Taming of Chance (Cambridge: Cambridge University Press, 1990). See also Mary Poovey, Making a Social Body: British Cultural Formation, 1830-1864 (Chicago: Chicago University Press, 1995); and Theodore M. Porter, Trust in Numbers: The Pursuit of Objectivity in Science and Public Life (Princeton: Princeton University Press, 1995).

63. Georges Canguilhem, The Normal and the Pathological (New York: Zone Books, 1991; originally published Le normal et le pathologique, 1966).

64. Julian B. Carter, The Heart of Whiteness: Normal Sexuality and Race in America, 1880-1940 (Durham and London: Duke University Press, 2007); Lennard J. Davis, Enforcing Normalcy: Disability, Deafness, and the Body (London: Verso, 1995); Rosemary Garland Thomson, Extraordinary Bodies: Figuring Physical Disability in American Culture and Literature (New York: Columbia University Press, 1997); and Sharon L. Snyder and David T. Mitchell, The Cultural Locations of Disability (Chicago: University of Chicago Press, 2006).

65. Lochrie's Heterosynchracies, while providing a useful overview of scholarship in "Have We Ever Been Normal?" (1-25), is largely intent on differentiating the medieval from the normal. See also Amy Hollywood, "The Normal, the Queer, and the Middle Ages" (173-78) in "History's Queer Touch: A Forum on Carolyn Dinshaw's Getting Medieval: Sexualities and Communities, Pre- and Postmodern," Journal of the History of Sexuality 10.2 (2001): 165-212.

66. One exception to this is the conference on "The Natural and the Normal in the History of Sexuality," held in September, 2008 at the Monash Center in Prato, Italy, the object of which was to tease out the historical and textual relations between the natural and the normal. The complex relation between nature and norms is alluded to, but not analyzed, in The Moral Authority of Nature, eds. Lorraine Daston and Fernando Vidal (Chicago: University of Chicago Press, 2004). In many respects, the focus of this anthology parallels my interest in norms, as the contributors seek, by providing a historical and cross-cultural account, "to shift the focus of inquiry from the existence and (il)legitimacy of nature's authority to its jurisdictions and workings" (2). They also acknowledge that "an inquiry into how, why, and where nature's authority is called on to buttress or subvert human norms requires a careful sorting out of the meanings of both nature and authority in specific contexts" (4). However, the undertheorized slippage from nature to norms in this comment is evident as well in Joan Cadden's otherwise excellent essay, "Trouble in Earthly Paradise: The Regime of Nature in Late Medieval Christian Culture” (207-31), 
in which she subtitles her final section "Norms Out of Nature," yet does not explicitly analyze the proposition implicit in this phrase.

67. Although I would want to nuance Paula Blank's assertion in Shakespeare and the Mismeasure of Man that "Shakespeare insists [. . . that 'measurement' must be understood as a figure of speech when it is applied to people, that human measurement is a metaphorical operation rather than an empirical one" (4), I agree with her contention that Shakespeare's "rhetoric of measurement [. . .] confirms the incommensurability of the quantifying methods of early physical science, the measure of time, matter, and space, with problems of 'human' knowledge" (5), as well as her point that Shakespeare's measures tend to be comparative, proceeding by correlation. For a history of quantification, see Alfred W. Crosby, The Measure of Reality: Quantification and Western Society, 1250-1600 (Cambridge: Cambridge University Press, 1997).

68. It is this, above all, that has led to the critical debate between stoicism versus Christianity in the play.

69. In interpreting Poor Tom as an empty signifier, I am aware of my collusion with the history of dispossession that Carroll, for instance, seeks to rewrite by historicizing the bedlam beggar ("The Bedlam Beggar"). In addition, as Carla Mazzio notes in The Inarticulate Renaissance: Language Trouble in an Age of Eloquence (Philadelphia: University of Pennsylvania Press, 2009), "When situated within norms of public interaction, the formation of unintelligible or self-referential sounds can quickly be taken for utterance emptied of content, detached from the humanizing dimensions of sociolinguistic decorum" (44). While Mazzio elucidates the conceptually productive dramatic import of linguistic incoherence, the fact remains that Poor Tom's speech remains largely unintelligible to his interlocutors, as well as to subsequent critics.

70. Such doubts can be discerned in the prefaces of early modern anatomy books as their authors defensively reassure readers that investigations of man's corporeal interior all are to the glory of God; see my analysis in The Renaissance of Lesbianism in Early Modern England (Cambridge: Cambridge University Press, 2002), 103-24.

71. As Brotten notes, "There is little doubt that as the play reaches its climax, he [Shakespeare] has also jettisoned the map as anything other than a vehicle to dramatize the initial disintegration of Lear and his kingdom. We have traveled so far from Lear's original meditation on geography that it almost seems absurd to ask what kind of map could represent 'the gored state' (5.3.319) with which the play concludes" ("Tragedy and Geography," 229).

72. Valerie Traub, "Mapping the Global Body," Early Modern Visual Culture: Representation, Race, and Empire in Renaissance England, eds. Peter Erickson and Clark Hulse (Philadelphia: University of Pennsylvania Press, 2000), 44-97.

73. For an astute examination of the relationship between mathematics, irrationality, and dramatic production, see Carla Mazzio, "The Three-Dimensional Self, Arts of Calculation: Quantifying Thought in Early Modern Europe, 39-65.

74. This appraisal is widely shared by major commentators on the play across the methodological spectrum; they include William Hazlitt, Charles Lamb, A. C. Bradley, Harold Bloom, Shakespeare: The Invention of the Human (New York: Riverhead Books, 1998); Stephen Greenblatt (Norton edition), and Kiernan Ryan, "King Lear," A Companion to Shakespeare's Works. Ann Thompson, King Lear (London: Macmillan, 1988), provides a useful overview.

75. Samuel Johnson, "Preface to the Edition of Shakespeare's Plays" (1765), Samuel Johnson on Shakespeare, ed. H. R. Woudhuysen (London: Penguin Books, 1989), 120-65, 
citation p. 122; emphases mine. Johnson of course is anticipated by those who praised Shakespeare as a poet of nature (see John Heminges and Henry Condell's preface and Ben Jonson's dedicatory poem in the First Folio).

76. Insofar as he sutures a structure of thought derived from the medieval past to a modern style of reasoning, Johnson reenacts the play's own temporal scope. That King Lear is located at the cusp of two broad periodizations is not a novel observation; it has become something of a critical cliché that Lear marks a transitional moment, whether between feudalism and capitalism, Christianity and secularism, or metaphysics and empiricism. In addition to Hillman, Shakespeare's Entrails, see Richard Halpern, "Historica Passio: King Lear's Fall into Feudalism," The Poetics of Primitive Accumulation: English Renaissance Culture and the Genealogy of Capital (Ithaca: Cornell University Press, 1991), 215-69; Walter Cohen, Drama of a Nation: Public Theater in Renaissance England and Spain (Ithaca: Cornell University Press, 1985), 327-56; and Stephen Greenblatt, "Shakespeare and the Exorcists," Shakespearean Negotiations: The Circulation of Social Energy in Renaissance England (Berkeley: University of California Press, 1988), 94-128.

77. Bradley, Shakespearean Tragedy, 200. In this, he was echoing Charles Lamb, who concluded that "Lear is essentially impossible to be represented on stage." See Henry Turner's reading of Bradley's assessment for its consideration of theater as a spatial art, The English Renaissance Stage, 159-63.

78. Greenblatt, Norton Shakespeare, 2311; see also Leggatt, King Lear: Harvester New Critical Introductions to Shakespeare, 12.

79. Bradley, Shakespearean Tragedy, 201.

80. Bradley, Shakespearean Tragedy, 210, 211.

81. Bradley, Shakespearean Tragedy, 212.

82. Bradley, Shakespearean Tragedy, 213.

83. Hodges, Renaissance Fictions of Anatomy, 87.

84. Margreta De Grazia, "The ideology of superfluous things: King Lear as period piece," Subject and Object in Renaissance Culture, eds. Margreta de Grazia, Maureen Quilligan, Peter Stallybrass (Cambridge: Cambridge University Press, 1996), 17-42, citation p. 21.

85. Ryan, "King Lear," 379. Through a critique of "the smug diagnostic attitude" of "the historicist criticism that currently holds sway" (377,390), Ryan aims to reveal Shakespeare's "proleptic cast of mind and propensity to fuse temporal horizons" (382) — what he later calls "the art of prescience" (384) or Lear's conception in "the future anterior" (388). While our recognition of the proleptic quality of Lear is similar, our assessment of universality is not.

86. If the aim of historical epistemology is to chart a genealogy of key concepts, it does so not merely to reaffirm accepted histories, but to enable our understanding to be reoriented by cultural traces carried imperceptibly within those histories. One effect, within the critical tradition on Lear, is to apprehend the similarity between the views of Danby and Williams, each of whom in his own way implies, but does not explain, a close correlation between nature and norms. Danby cannot discuss nature without continual reference to norms, going so far as to call Goneril, Regan, and Edmund "eminently normal people" (The Doctrine of Nature, 42; 50).

87. De Grazia, "The ideology of superfluous things," 34. 